\title{
Current Status of the Ferns and Lycophytes of the Hawaiian Islands
}

\author{
Amanda L. Vernon and Tom A. RANKer \\ University of Hawai'i at Mānoa, Department of Botany, 3190 Maile Way, Room 101, Honolulu, \\ HI 96822 USA, e-mail: amandaleevernon@gmail.com e-mail: ranker@hawaii.edu
}

\begin{abstract}
The Hawaiian Islands are well known for having one of the highest documented percentages of endemic plants in the world. Hawaiian ferns and lycophytes represent a relatively large percentage of the endemic flora with approximately $74 \%$ of the native fern and lycophyte species considered endemic. In addition, at least 40 taxa are naturalized aliens. We present a new synopsis of the Hawaiian fern and lycophyte flora that includes new state and island records, recent taxonomic updates and problems, and a summary of known and hypothesized geographical origins of fern and lycophyte lineages. We also provide a checklist and access to an interactive key to the native and naturalized ferns and lycophytes of the Hawaiian Islands (http://www.herbarium. hawaii.edu/lucid/ferns/introduction.html).
\end{abstract}

KEY WoRDs.-Hawaii, fern, lycophyte, checklist, interactive key

There are 159 native species of ferns and lycophytes in the Hawaiian Islands. Although these represent only about $15 \%$ of the native vascular plant flora of the islands (159 fern and lycophyte species: 1032 flowering plant species) (W. L. Wagner, pers. comm. and W. L. Wagner et al., 2005-), fern species are often common components of the vegetation of many mesic to wet plant communities and are sometimes the dominant species both in numbers of individuals and in total biomass (e.g., see Gagné and Cuddihy, 1999). In addition to the native fern and lycophyte taxa, there are now 40 introduced and naturalized taxa, some of which are becoming invasive. Thus, an accurate knowledge of fern and lycophyte diversity in the Hawaiian Islands is important for both basic ecological and evolutionary studies and for conservation management purposes. During the course of preparing an interactive, online key to the ferns of the Hawaiian Islands (see: http://www. herbarium.hawaii.edu/lucid/ferns/introduction.html), we conducted a thorough review and analysis of the taxonomic history of Hawaiian ferns and lycophytes. We present here a summary of those studies, including the history of collecting, an overview of fern and lycophyte diversity in the islands, estimates of the geographical origins of native Hawaiian fern and lycophyte lineages, additions to the known flora since the publication of the last floristic inventory (Palmer, 2003), and recent taxonomic changes.

\section{Synopsis of Hawaiian Fern and Lycophyte Floras and Enumerations}

It was upon Captain James Cook's voyage of the HMS Resolution in 1778 that the first collections of Hawaiian plants were made by the naturalist William Anderson (W. L. Wagner et al., 1999). Anderson made a single collection, 
Argemone glauca Pope, and noted 22 plant taxa occurring on the island of Kaua'i. The following year, David Nelson, an apprentice botanist aboard Cook's Resolution sister ship the Discovery, collected approximately 136 vascular plant specimens (St. John, 1978; W. L. Wagner et al., 1999). Although the ship made excursions to Ni'ihau, Kaua'i, Maui, and Hawai'i, Nelson was able to explore only the island of Hawai'i. The specimens from these voyages are housed at the Natural History Museum in London. Archibald Menzies and Albert Chamisso also were early collectors of Hawaiian plants. Menzies explored five of the Hawaiian Islands from 1788 to 1794 (W. L. Wagner et al., 1999). Chamisso collected in the 1810 s on O'ahu and later published species descriptions in the journal Linnaea (Robinson, 1912a).

Charles Gaudichaud was the botanist aboard Louis de Freycinet's voyage of the Uranie that explored O'ahu, Maui, and Hawai'i for twenty days in 1819, although only seven days were spent on land (St. John and Titcomb, 1983). Gaudichaud collected 4,175 specimens throughout the journey (1817-1820), but unfortunately 2,500 of those were lost in a shipwreck. In 1826, he published his account of Hawaiian ferns and lycophytes in Botanique du Voyage autour du monde (Gaudichaud, 1826). He included descriptions for 52 genera and 268 species of ferns and lycophytes. Of these, 17 genera and 37 species were from the Hawaiian Islands.

Between 1825 and 1834, James Macrae, George T. Lay, and David Douglas made collections of Hawaiian ferns and lycophytes (Robinson, 1912a; W. L. Wagner et al., 1999). The botanist William Brackenridge visited the Hawaiian Islands from 1840-1841, as part of the United States Exploring Expedition under the command of Charles Wilkes (W. L. Wagner et al., 1999). Throughout the expedition, he recorded numerous ferns and lycophytes and published brief descriptions for all species, and he also included 46 plates with detailed illustrations (Brackenridge, 1971). Unfortunately the majority of the copies of this publication were destroyed in a fire and only 12 copies were salvaged (Robinson, 1912a). Images of Brackenridge's plates may be viewed at the Smithsonian Institution Libraries website: http://www.sil.si.edu/imagegalaxy/ imageGalaxy_MoreImages.cfm?book_id=19-24a.

Several enumerations and diagnostic keys of Hawaiian ferns were made between 1864 and 1887. William T. Brigham and Horace Mann visited Kaua'i, O'ahu, Maui, Moloka'i, and Hawai'i and made a checklist of 113 fern species (Robinson, 1912a). John M. Lydgate (1873) published a synopsis of Hawaiian ferns that included descriptions of 24 genera and keys to 111 taxa. Derby (1875) published a checklist that included 124 fern and 15 lycophyte taxa. Several years later, Edward Bailey (1883) wrote a summary of the Hawaiian ferns that included 149 species, each with descriptions and several with elevational and habitat data, although no identification keys were included. Lorenzo G. Yates (1887) published an enumeration of Hawaiian ferns (129 species) that lacked species descriptions, but which incorporated some habitat and elevational information for most species.

William Hillebrand (1888) spent 20 years in the Hawaiian Islands working as a physician and developing his skills as a botanist. At the time of his death in 
1886, part of his manuscript of "The Flora of the Hawaiian Islands" was with the printer. It was not until 1888 that the flora was published. The flora contains generic and specific keys and detailed descriptions for flowering plants, ferns, and lycophytes, including distributional and ethnobotanical information. Hillebrand recognized 29 fern genera with 140 species and two lycophyte genera with 15 species. He also acknowledged numerous varieties (approximately 50 fern and four lycophyte varieties) with the majority occurring within Asplenium species.

In 1890, A. B. Lyons created a diagnostic key to the Hawaiian ferns that included a key to genera and species, but he did not include species descriptions. Lyons included 27 genera and 143 taxa (139 species, three varieties, and one undetermined species) (Lyons, 1890). Seven years later, Amos A. Heller (1897) published a report of his observations of plants of the Hawaiian Islands. He provided brief descriptions for 106 fern and lycophyte taxa, including six newly described species, and illustrations for two species. Winifred J. Robinson published four papers over the course of three years (1912-1914) that included keys and detailed descriptions to the families, genera, and species of Hawaiian ferns and lycophytes. She recognized more genera and species than any previous treatment: 43 genera and 166 species of ferns and lycophytes (Robinson, 1912a, 1912b, 1913, 1914). Her treatment included numerous plates of photographs of herbarium specimens along with species descriptions that included synonyms, type localities, distribution, and ethnobotanical uses. Copeland published two papers in which he described several new species and updated the nomenclature for fern collections he received from M. L'abbé Faurie (1914) and Joseph F. Rock (1916).

Several years later, Vaughan MacCaughey focused on the ecological relationships of Hawaiian ferns and lycophytes, and recognized 44 genera and 190 species (MacCaughey, 1918). Carl Christensen revised the nomenclature of the Hawaiian ferns and lycophytes to follow his Index Filicum (1906). He published a checklist that accepted 41 genera with 159 fern and lycophyte taxa (Christensen, 1925). Although he did not include identification keys, he did provide additional notes on some species and groups that are in need of further study.

Robert L. Fowler (1940) created an annotated checklist of the ferns and lycophytes of the Kilauea-Mauna Loa section of Hawai'i Volcanoes National Park. His list included six lycophyte species and 60 fern taxa; some taxa included information on where they could be located within the park. In 1952, Douglass H. Hubbard created a booklet of the most common ferns of Hawai'i National Park that included images for 63 species and brief descriptions of the genera. From 1932 to 1980, Otto and Isa Degener published a series of looseleaf books on the Hawaiian vascular plant flora (Degener, 1932-1980). Their publications include generic and species descriptions and keys, distributional information, and numerous illustrations for 94 fern and 14 lycophyte taxa. During the 1980s Warren H. Wagner Jr. published two papers in the Fiddlehead Forum that briefly described the status of the Hawaiian ferns and lycophytes, based on years of field experience by himself and Florence 
S. Wagner. In 1981, he presented a checklist of approximately 180 fern and lycophyte taxa (W. H. Wagner, 1981). Seven years later he reported 198 taxa, 172 native (118 endemic) and 26 naturalized, although he acknowledged uncertainties about the exact total number of taxa (W. H. Wagner, 1988).

The two most recent Hawaiian fern and lycophyte floras are from Kathy Valier (1995) and Daniel D. Palmer (2003). Valier did not treat all the Hawaiian ferns and lycophytes, but rather provided descriptions for 61 of the most commonly encountered taxa. She reported, in accordance with W. H. Wagner (1988), about 200 fern and lycophyte taxa, 172 being native. The most up-todate and comprehensive Hawaiian fern and lycophyte flora is that of Palmer (2003), which included descriptions of fern and lycophyte families, genera, and species along with keys to genera and species and numerous illustrations. Palmer recognized 73 genera and 221 taxa (including hybrids) of Hawaiian ferns and lycophytes. The species descriptions highlight characters that separate each species from similar species and include information on synonyms, current distribution, habitat, elevation, ethnobotanical knowledge, and vernacular names. Palmer was able to record the variability found throughout Hawaiian ferns and lycophytes by observing numerous specimens in the field and in herbaria and including first-hand observations of many type specimens.

\section{Current Treatment}

The Hawaiian Islands have representatives from all major lineages of monilophytes except the Equisetopsida and from all three lineages of lycophytes. The endemic fern genera of the Hawaiian Islands have long been thought to consist of Adenophorus (Polypodiaceae), Diellia (Aspleniaceae), and Sadleria (Blechnaceae). [N.B. Authorities for all Hawaiian taxa are given in Appendix 1.] However, molecular work by Schneider et al. (2004a, 2005) supported Diellia as a monophyletic clade nested within Asplenium (Aspleniaceae), therefore decreasing the number of endemic fern genera to two. This classification is recognized in the majority of recent treatments (Christenhusz et al., 2011; Smith et al., 2006, 2008; Snow et al., 2011; Viane and Reichstein, 1991). There are presently 144 native fern species (167 taxa) and 15 native lycophyte species (16 taxa), not including hybrids in the Hawaiian Islands. The genera with the most Hawaiian fern taxa are Asplenium (29 taxa), Dryopteris (20 taxa), and Adenophorus (12 taxa). A synopsis of the statistics of the Hawaiian fern and lycophyte flora is given in Table 1.

\section{New Fern Records in the Hawaiian Islands}

Several new state and island records of native and naturalized ferns have been published since Palmer's flora (2003), including seven new state records of naturalized ferns (Table 2). In addition, 20 new island records have been reported, most of which are also naturalized ferns. One new island record of a native species is of the endemic Asplenium haleakalense, which was 
TABLE 1. Current statistics for the ferns and lycophytes of the Hawaiian Islands ${ }^{1}$.

\begin{tabular}{lrcc}
\hline & Ferns & Lycophytes & $\begin{array}{c}\text { Total ferns and } \\
\text { lycophytes }\end{array}$ \\
\hline Families & 25 & 3 & 28 \\
Endemic genera & 2 & 0 & 2 \\
Genera with all naturalized species & 16 & 0 & 16 \\
Indigenous genera & 48 & 5 & 53 \\
Native genera & 50 & 5 & 55 \\
$\quad$ Total genera & 66 & 5 & 71 \\
Endemic species & 110 & 7 & 117 \\
Indigenous species & 34 & 8 & 42 \\
$\quad$ Total native species & 144 & 15 & 159 \\
Endemic hybrids & 18 & 6 & 24 \\
Indigenous hybrids & 0 & 0 & 0 \\
$\quad$ Total native hybrids & 18 & 6 & 140 \\
Endemic taxa * & 132 & 8 & 43 \\
Indigenous taxa * & 35 & 8 & 183 \\
$\quad$ Total native taxa * & 167 & 16 & 36 \\
Naturalized species & 33 & 3 & 40 \\
Naturalized taxa * & 37 & 3 & 195 \\
Total native and naturalized species & 177 & 18 & 223 \\
Total native and naturalized taxa * & 204 & 19 & 247 \\
Total native and naturalized taxa * & 222 & 25 & \\
\hline
\end{tabular}

${ }^{1}$ includes species presumed extinct

* includes subspecies, varieties, and cultivars, but does not include forms or hybrids

** includes subspecies, varieties, cultivars, and hybrids

described in 1999 and known previously only from Maui (Palmer, 2003). A specimen at the Herbarium Pacificum (BISH) collected on Hawai'i in 1995 was determined as $A$. haleakalense by Dan Palmer in 2002, thus representing a new island record for this species (Kennedy et al., 2010). Microlepia speluncae (Dennstaedtiaceae) is another example of a new island record for a native species. Palmer (2003) reported the species to be distributed on the islands of Kaua'i, O'ahu, and Hawai'i, but it has been documented subsequently on Maui (Oppenheimer, 2003) and Moloka'i (Oppenheimer, 2008).

Four noteworthy rediscoveries include Asplenium diellaciniatum (syn. Diellia laciniata), Asplenium dielmannii (syn. Diellia mannii), Ctenitis squamigera (Dryopteridaceae), and Pteris lidgatei (Pteridaceae) (Table 2). Asplenium diellaciniatum was rediscovered on the island of Kaua'i (Wood, 2006). Palmer (2003) recognized this taxon as a form of the federally listed species, Diellia erecta (f. alexandri), and noted it was likely extinct on Kaua'i. Recent morphological studies by Lorence et al. (in press) conclude that Diellia erecta f. alexandri represents two distinct species with one endemic to Kaua'i (Asplenium diellaciniatum) and the other to Maui Nui. In 2004, a population of 49 individuals was discovered on slopes of the Kawai'iki Stream in western Kaua'i (Wood, 2006). The most recent report documents a decline in the population to 39 individuals (USFWS, 2009a). Currently the species is not 


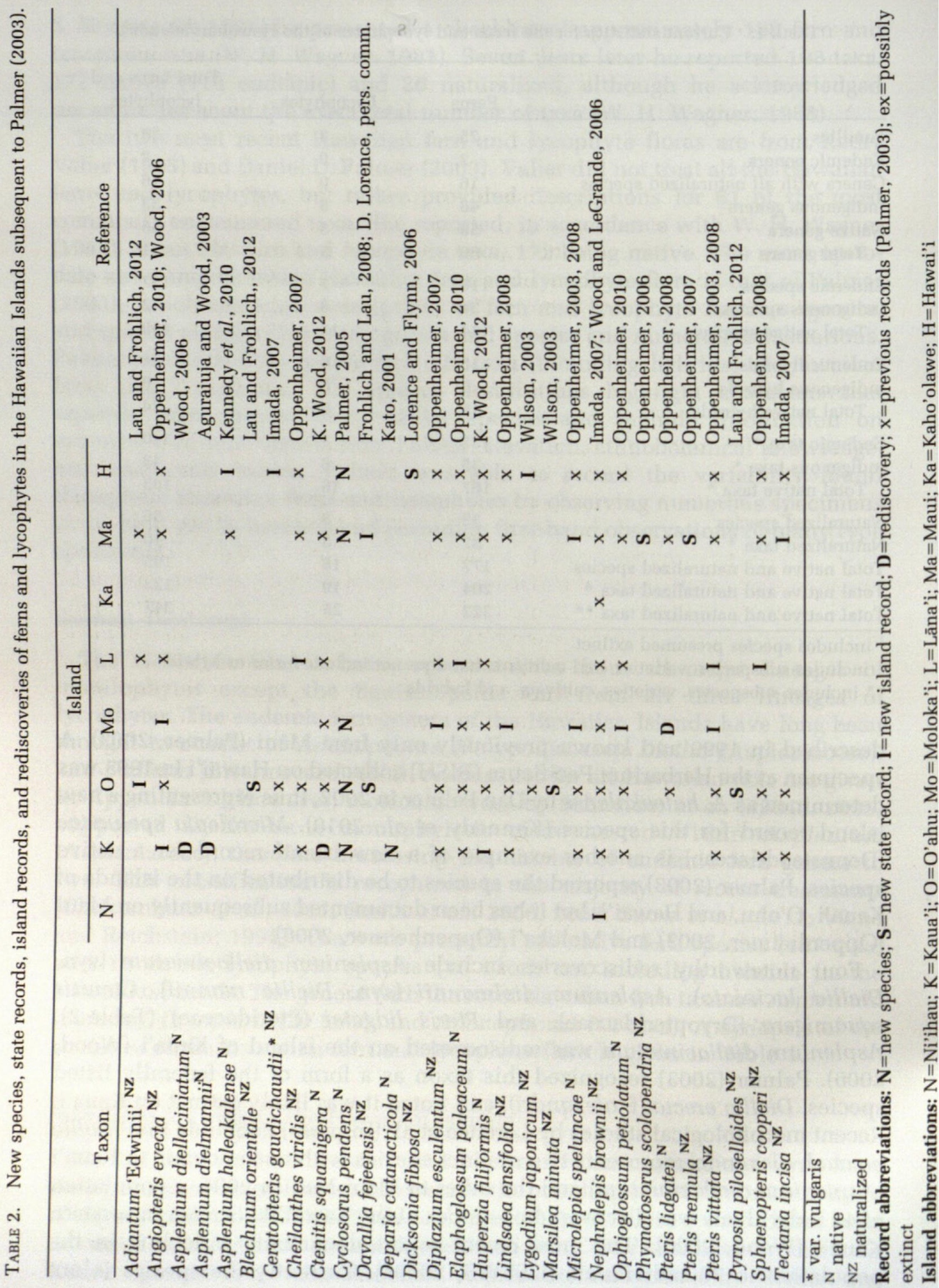


federally listed or proposed for listing. As discussed later, the presumed extinct fern, Asplenium dielmannii, was also rediscovered on Kaua'i (Aguraiuja and Wood, 2003).

Another rediscovery on Kaua'i is that of Ctenitis squamigera, a species previously known from all main Hawaiian Islands with the exception of Kaho'olawe and Ni'ihau. It was last collected on Kaua'i in the late 1800's and thus presumed extinct on the island until its rediscovery in two separate locations in 2011 (K. Wood, 2012). Pteris lidgatei was rediscovered on the island of Moloka'i (Oppenheimer, 2007). Its last known collection on Moloka'i was in 1912, and since then had been considered extinct on the island (Oppenheimer, 2007; Palmer, 2003; W. H. Wagner et al., 1999). On Moloka'i, eight individuals are known from a single population (USFWS, 2009b).

An interesting island record is that of Psilotum nudum (Psilotaceae). Although present on all main Hawaiian Islands including Ni'ihau and Kaho'olawe, $P$. nudum was never reported from any Northwestern Hawaiian Island (Palmer, 2003). A collection of $P$. nudum made in 1923 from Midway Atoll was discovered in 2008 in the collections of the Herbarium Pacificum (Kennedy et al., 2010). Two other possible island records, based on herbarium specimens, are of Doryopteris angelica (Pteridaceae) and D. takeuchii. Yesilyurt (2005) proposed that the endangered Kaua'i endemic, Doryopteris angelica, has a more extensive distribution than had been previously reported (Palmer, 2003) occurring on O'ahu, Moloka'i, and Lāna'i. She also determined a range extension for the endangered (USFWS, 2012a) Doryopteris takeuchii, to the island of Lāna'i, previously thought to be endemic to Diamond Head Crater on O'ahu. It is imperative to note that Yesilyurt's (2005) conclusions were based on relatively few older herbarium specimens (5 specimens of $D$. takeuchii and 11 specimens of $D$. angelica), and she did not observe the type specimens for either species. For these reasons and because both of these ferns are currently federally listed endangered species it is important that new field observations be made to assess the current distribution of these two species before we accept the range extensions proposed by Yesilyurt (2005).

\section{Newly Described Hawaiian Fern Taxa}

Only one native species, Cyclosorus pendens (syn. Pneumatopteris pendens; Thelypteridaceae), has been described since Palmer's (2003) manual was published (Palmer, 2005). This species is found on Kaua'i, O'ahu, Moloka'i, Maui, and Hawai'i at elevations of $368-1220 \mathrm{~m}$ and is most similar morphologically to $C$. sandwicensis (Palmer, 2005). Characters that define $C$. pendens are a habitat of damp, mossy rocks often near streams and pendent, lanceolate leaves with obtuse pinnae and rachises and costae that are densely covered with hairs (Palmer, 2005).

Another species not included in Palmer (2003) is Deparia cataracticola (Athyriaceae), of which the author was unaware when his book was in press (D. Palmer, pers. comm.). This species is endemic to Kaua'i and is found on wet, mossy cliffs in waterfalls, a habitat similar to where the extinct $D$. 
kaalaana was found (Kato, 2001). Deparia cataracticola is recognizable by having an ascending to erect rhizome, brown scales at the stipe base, medial sori, leaf blades that are somewhat or not tapered at the base, and by the presence of many proliferations on the lamina (Kato, 2001).

Two species of Hawaiian Doryopteris that were not included by Palmer (2003) have recently been recognized. Yesilyurt (2005) recognized six species of Doryopteris in the Hawaiian Islands, whereas Palmer (2003) recognized four species and one hybrid. The Hawaiian species of Doryopteris are known to have extreme inter- and intraspecific variability, leading to difficulties when circumscribing species (Palmer, 2003; Yesilyurt, 2005). For example, Doryopteris subdecipiens was first described by W. H. Wagner et al. (1999) who noted that it most likely was the result of hybridization between $D$. decipiens and $D$. decora. Palmer (2003) preferred to recognize $D$. subdecipiens as a hybrid due to its variability of characters and the continuum of intermediates between the putative parental species. The morphological study by Yesilyurt (2005) recognized this entity at the species level, although she did not rule out the possibility of it being of hybrid origin. She did not examine the type specimen and only examined nine herbarium specimens for which she noted much variation (Yesilyurt, 2005). We agree with Palmer (2003) that this species should not be recognized at the species level due to its variability and intermediate characters between the parent species. Another species, $D$. tryonii, was described in 1963 by O. Degener and I. Degener, but later synonymized under $D$. decora by Palmer (2003). Yesilyurt (2005) segregated this species based on its filiform segments, pinnate division, and crenulate indusium margins. Because the Hawaiian Doryopteris species exhibit high morphological variation and possibly hybridization, it is unclear whether they represent distinct species. Further studies are needed to clarify species circumscriptions.

\section{Naturalized Hawaiian Fern Taxa}

Palmer (2003) reported 33 naturalized fern and lycophyte taxa in the Hawaiian Islands. Since then, seven new state records of naturalized ferns have been reported, including taxa from previously unreported families and genera in the Hawaiian Islands (Table 3). Two previously unreported families include Davalliaceae and Dicksoniaceae, and three previously unreported genera include Davallia (Davalliaceae), Dicksonia (Dicksoniaceae), and Pyrrosia (Polypodiaceae).

Naturalized taxa are found on all eight main Hawaiian Islands, with O'ahu having the majority of naturalized taxa (Figure 1; Table 3). Three naturalized species, Nephrolepis brownii (Nephrolepidaceae), Pityrogramma austroamericana (Pteridaceae), and $P$. calomelanos, are found on all main Hawaiian Islands. Listed below are the seven recent new state records based on the work of Hank Oppenheimer, Ken Wilson, and the staff at the Hawai'i Biological Survey and the National Tropical Botanical Garden. 
TABLE 3. Current distribution of naturalized fern and lycophyte taxa in the Hawaiian Islands.

\begin{tabular}{|c|c|c|c|c|c|c|c|c|}
\hline \multirow[b]{2}{*}{ Taxon } & \multicolumn{8}{|c|}{ Island } \\
\hline & $\mathrm{N}$ & $\mathrm{K}$ & $\mathrm{O}$ & Mo & $\mathrm{L}$ & Ка & $\mathrm{Ma}$ & $\mathrm{H}$ \\
\hline Adiantum 'Edwinii' & & & $\mathrm{x}$ & & $\mathrm{x}$ & & $\mathrm{x}$ & \\
\hline Adiantum hispidulum & & $\mathrm{x}$ & $\mathrm{x}$ & $\mathrm{x}$ & $\mathrm{x}$ & $\mathrm{x}$ & $\mathrm{x}$ & $\mathrm{x}$ \\
\hline Adiantum raddianum & & $\mathrm{x}$ & $\mathrm{x}$ & $\mathrm{x}$ & $\mathrm{x}$ & & $\mathrm{x}$ & $\mathrm{x}$ \\
\hline Adiantum tenerum & & & $\mathrm{x}$ & & & & $\mathrm{x}$ & \\
\hline Angiopteris evecta & & $\mathrm{x}$ & $\mathrm{x}$ & $\mathrm{x}$ & $\mathrm{x}$ & & $\mathrm{x}$ & $\mathrm{x}$ \\
\hline Azolla filiculoides & & $\mathrm{x}$ & $\mathrm{x}$ & $\mathrm{x}$ & $\mathrm{x}$ & & $\mathrm{x}$ & $\mathrm{x}$ \\
\hline Blechnum appendiculatum & & $\mathrm{x}$ & $\mathrm{x}$ & $\mathrm{x}$ & $\mathrm{x}$ & & $\mathrm{x}$ & $\mathrm{x}$ \\
\hline Blechnum orientale * & & & $\mathrm{x}$ & & & & & \\
\hline Ceratopteris gaudichaudii var. vulgaris & & $\mathrm{x}$ & $\mathrm{x}$ & & & & & $\mathrm{x}$ \\
\hline Cheilanthes viridis & & $\mathrm{x}$ & $\mathrm{x}$ & & $\mathrm{x}$ & & $\mathrm{x}$ & $\mathrm{x}$ \\
\hline Cyclosorus dentatus & & $\mathrm{x}$ & $\mathrm{x}$ & $\mathrm{x}$ & $\mathrm{x}$ & & $\mathrm{x}$ & $\mathrm{x}$ \\
\hline Cyclosorus parasiticus & & $\mathrm{x}$ & $\mathrm{x}$ & $\mathrm{x}$ & $\mathrm{x}$ & & $\mathrm{x}$ & $\mathrm{x}$ \\
\hline Cyrtomium falcatum & & $\mathrm{x}$ & $\mathrm{x}$ & $\mathrm{x}$ & $\mathrm{x}$ & & $\mathrm{x}$ & $\mathrm{x}$ \\
\hline Davallia fejeensis * & & & $\mathrm{x}$ & & & & $\mathrm{x}$ & \\
\hline Deparia petersenii & & $\mathrm{x}$ & $\mathrm{x}$ & $\mathrm{x}$ & $\mathrm{x}$ & & $\mathrm{x}$ & $\mathrm{x}$ \\
\hline Dicksonia fibrosa * & & & & & & & & $\mathrm{x}$ \\
\hline Diplazium esculentum & & $\mathrm{x}$ & $\mathrm{x}$ & $\mathrm{x}$ & $\mathrm{x}$ & $x=$ & $\mathrm{x}$ & $\mathrm{x}$ \\
\hline Lindsaea ensifolia & & $\mathrm{x}$ & $\mathrm{x}$ & $\mathrm{x}$ & & 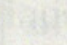 & $\mathrm{x}$ & $\mathrm{x}$ \\
\hline Lygodium japonicum & & & $\mathrm{x}$ & & & & & $\mathrm{x}$ \\
\hline Macrothelypteris torresiana & & $\mathrm{x}$ & $x$ & & & & $\mathrm{x}$ & $\mathrm{x}$ \\
\hline Marsilea minuta * & & & $\mathrm{x}$ & & & & & \\
\hline Nephrolepis brownii & $\mathrm{x}$ & $\mathrm{x}$ & $\mathrm{x}$ & $\mathrm{x}$ & $\mathrm{x}$ & $\mathrm{x}$ & $\mathrm{x}$ & $\mathrm{x}$ \\
\hline Nephrolepis falcata 'Furcans' & & $\mathrm{x}$ & $\mathrm{x}$ & $\mathrm{x}$ & $\mathrm{x}$ & & $\mathrm{x}$ & $\mathrm{x}$ \\
\hline Nephrolepis hirsutula 'Superba' & & $\mathrm{x}$ & & & & & $\mathrm{x}$ & \\
\hline Phlebodium aureum & & $\mathrm{x}$ & $\mathrm{x}$ & $\mathrm{x}$ & $\mathrm{x}$ & & $\mathrm{x}$ & $\mathrm{x}$ \\
\hline Phymatosorus grossus & & $x$ & $x$ & $\mathrm{x}$ & $\mathrm{x}$ & 18 & $\mathrm{x}$ & $\mathrm{x}$ \\
\hline Phymatosorus scolopendria * & & & & & & & $\mathrm{x}$ & \\
\hline Pityrogramma austroamericana & $\mathrm{x}$ & $\mathrm{x}$ & $\mathrm{x}$ & $\mathrm{x}$ & $\mathrm{x}$ & $\mathrm{x}$ & $\mathrm{x}$ & $\mathrm{x}$ \\
\hline Pityrogramma calomelanos & $\mathrm{x}$ & $\mathrm{x}$ & $\mathbf{x}$ & $\mathrm{x}$ & $\mathbf{x}$ & $x$ & $\mathrm{x}$ & $\mathbf{x}$ \\
\hline Platycerium bifurcatum & & & $\mathrm{x}$ & & & & $\mathrm{x}$ & $\mathrm{x}$ \\
\hline Platycerium superbum & & & $\mathrm{x}$ & & & & & \\
\hline Pteris tremula * & & & & & & & $\mathrm{x}$ & \\
\hline Pteris vittata & & $\mathrm{x}$ & $x$ & $\mathrm{x}$ & $\mathrm{x}$ & & $\mathrm{x}$ & $\mathrm{x}$ \\
\hline Pyrrosia piloselloides * & & & $\mathrm{x}$ & & & & & \\
\hline Salvinia molesta & & & $\mathbf{x}$ & & & & & $x$ \\
\hline Selaginella kraussiana & & & $x$ & & & & $\mathrm{x}$ & $\mathrm{x}$ \\
\hline Selaginella stellata & & & & & & & & $\mathrm{x}$ \\
\hline Selaginella umbrosa & & & & & & & & $\mathrm{x}$ \\
\hline Sphaeropteris cooperi & & $\mathrm{x}$ & $\mathrm{x}$ & & $\mathbf{x}$ & & $\mathrm{x}$ & $\mathbf{x}$ \\
\hline Tectaria incisa & & $\mathrm{x}$ & $\mathrm{x}$ & & & & $\mathrm{x}$ & $\mathrm{x}$ \\
\hline
\end{tabular}

* indicates new state record subsequent to Palmer (2003)

Hawaiian Island abbreviations: N=Ni'ihau; $\mathrm{K}=\mathrm{Kaua} i$; $\mathrm{O}=\mathrm{O}$ 'ahu; Mo=Moloka'i; L=Lāna'i; $\mathrm{Ma}=$ Maui; $\mathrm{Ka}=$ Kaho'olawe; $\mathrm{H}=$ Hawai'i

Blechnum orientale (Blechnaceae) was discovered naturalized in two locations on the island of O'ahu in 2010 (Lau and Frohlich, 2012). It is native to tropical Asia, Australia, and several Pacific Islands (Chambers and Farrant, 2001; Chiou et al., 1994). Diagnostic characters include rhizomes that are short, 


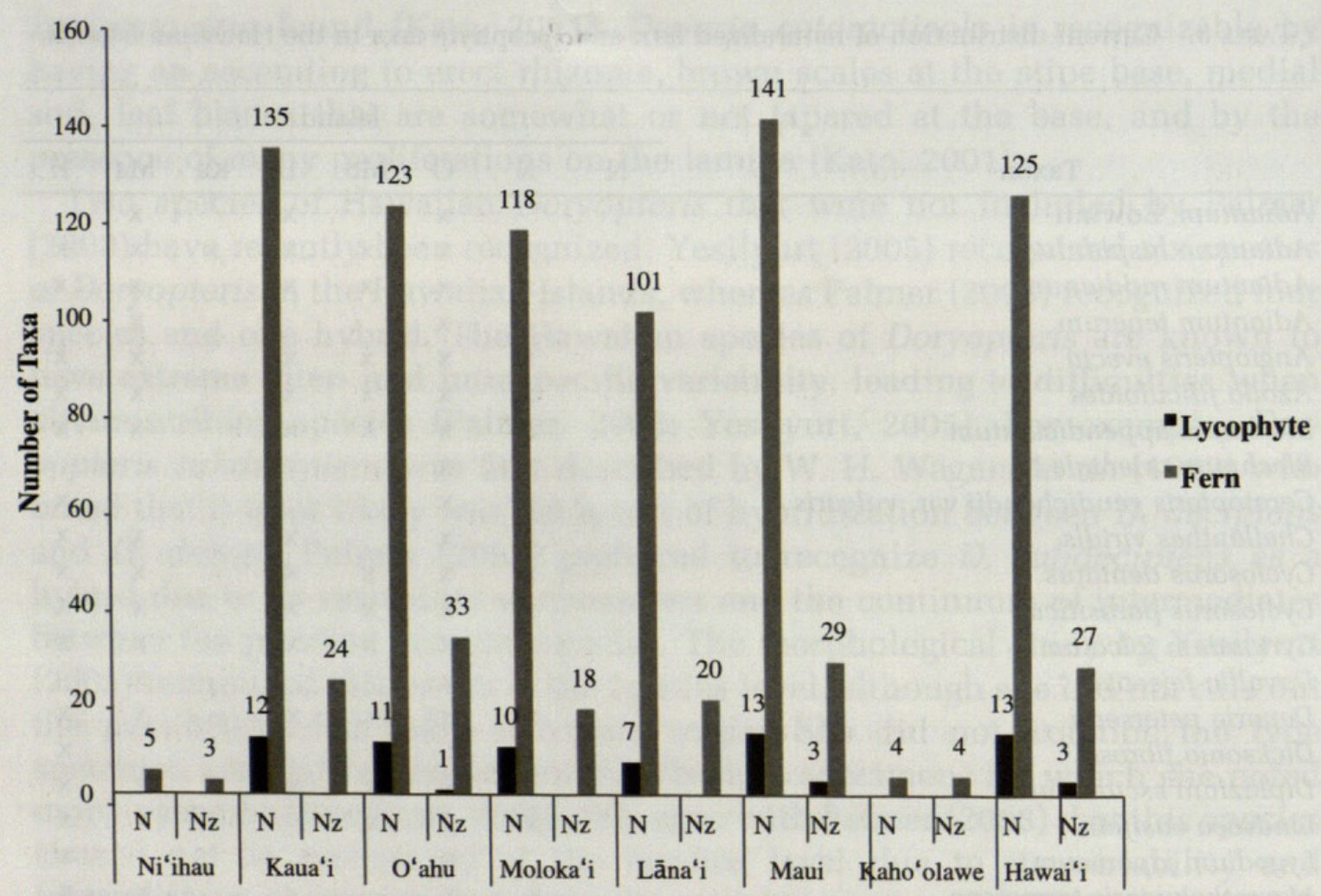

FIG. 1. Native $(\mathrm{N})$ and naturalized (NZ) fern and lycophyte taxa on the eight main Hawaiian Islands. The total taxa per island includes taxa presumed extinct.

erect, and trunk-like; fronds up to $200 \mathrm{~cm}$ or more with blades pinnately divided; pinnae 5-30 cm long; and sori that are linear, costal, and indusiate.

Davallia fejeensis (Davalliaceae), a native to the Fiji Islands, was first reported naturalized on O'ahu in 2007 in the Nu'uanu Valley (Frohlich and Lau, 2008). The authors reported $D$. fejeensis as being widely cultivated on O'ahu and likely cultivated on other islands as well. A collection of this species (Lorence 10375, PTBG) was recently made near Haiku in eastern Maui (D. Lorence, pers. comm.). This species is identified by its epiphytic or sometimes terrestrial habitat, creeping rhizomes, blades that are divided 4-5 times with linear ultimate segments bearing a single vein that does not touch the margin, and sori that are solitary at segment tips (Morton, 1957; Nooteboom, 1994).

Dicksonia fibrosa (Dicksoniaceae), a New Zealand native tree fern, was reported naturalized in one locality in the South Hilo district on the island of Hawai'i (Lorence and Flynn, 2006). This species is distinguished from other Hawaiian ferns by trunks that reach $30-60 \mathrm{~cm}$ in diameter and up to $6 \mathrm{~m}$ tall, stipes with brown hairs, 20-30+ leaves per plant, blades that gradually taper towards the base, and bivalved indusia with the outer valve not differentiated from the lamina (Alan, 1982).

The first record of the aquatic fern Marsilea minuta (syn. M. crenata (Nagalingum et al., 2007; Whitten et al., 2012)) (Marsileaceae) is puzzling. Hillebrand (1888) reported $M$. minuta (treated as $M$. crenulata) on O'ahu, 
preserved in the "Godet herbarium," although Robinson (1912a) reported that no such herbarium was known. Further investigation into the location of this specimen has been unsuccessful, although other collections from the Godet herbarium have been found at the Botanic Garden and Botanical Museum Berlin-Dahlem herbarium (B). The most recent record of Marsilea minuta was made in 1994 when it was found growing in taro patches at the Hawai'i Nature Center in Makiki Valley on O'ahu (Wilson, 2002, 2003). Marsilea minuta is native to Africa, Australia, India, and Southeast Asia (Jacona and Johnson, 2006). It is morphologically similar to the endemic $M$. villosa, which also has an aquatic habit, pinnae that are clover-like (divided into four equal pinnae), and sori enclosed in hardened sporocarps located at the bases of long stipes. This naturalized species is readily distinguished from the endemic species by its usually glabrous blades (sometimes with a few scattered hairs) with crenate pinnae margins (entire margins in aquatic forms) (Jacona and Johnson, 2006), in contrast with the glabrous blades and slightly denticulate pinnae margins of M. villosa (Johnson, 1986; Palmer, 2003). Furthermore, the naturalized species has roots located at nodes and internodes (Jacona and Johnson, 2006), whereas $M$. villosa has roots restricted to the nodes (Johnson, 1986).

Two populations of Phymatosorus scolopendria (Polypodiaceae) were reported on Maui (Oppenheimer, 2006). A collection of this species was made (Oppenheimer \& Hansen H80308, BISH), but cannot be located for verification. Phymatosorus scolopendria is native to tropical Africa and Asia, Australia, and the Pacific (Brownlie, 1977). This species closely resembles and can easily be mistaken for a common naturalized fern, $P$. grossus, but is distinguished by its epiphytic habit (vs. terrestrial), smaller size, and fewer laminar lobes (Brownlie, 1977).

Pyrrosia piloselloides was found naturalized in a 2-3 acre area in the Woodlawn section of Mānoa Valley on the island of O'ahu in 2010 (Lau and Frohlich, 2012). This species is native to China, India, and Malesia (Ravensberg and Hennipman, 1986). Pyrrosia piloselloides is a small, epiphytic, colony-forming fern diagnosable by its sterile succulent leaves reaching 1-7 cm long, fertile linear leaves from 4-16 cm long, and linear, submarginal sori (Hovenkamp, 1986).

Pteris tremula was first reported as naturalized on Maui (Oppenheimer, 2007), when it was noted as becoming widespread throughout the central Kula areas at elevations from 914 to $1220 \mathrm{~m}$. No further report has been found concerning its distributional status in the Hawaiian Islands. This species is native to Australia, New Zealand, and the Fiji Islands; it is identified by its erect leaves that attain one meter in length and blades that are 2-4 times pinnately divided with linear, toothed pinnules (Kramer and McCarthy, 1998).

\section{Taxonomic Updates}

Smith et al. (2006) revised the familial classification for all extant ferns based on the results of numerous molecular and morphological studies. They recognized 37 families with approximately 265 to 312 genera. A more recent 
classification for extant ferns and lycophytes by Christenhusz et al. (2011) built upon the classification of Smith et al. (2006) with recent phylogenetic studies. Christenhusz et al. (2011) recognized 3 families with 5 lycophyte genera and 45 families with approximately 280 fern genera. Snow et al. (2011) addressed the need to update the taxonomy and nomenclature of the Hawaiian ferns and lycophytes. Their treatment primarily followed the classification by Smith et al. $(2006,2008)$. Rothfels et al. (2012b) reexamined the classification of the Eupolypods II and recognized 10 families with 36 genera. A recent classification of the Lycopodiaceae by Øllgaard (2012) accepts 9 Neotropical genera. Although these publications clarify the classification of extant ferns and lycophytes, it is important to note that many fern and lycophyte genera lack molecular studies and are in need of phylogenetic analyses to assess proposed generic delimitations (Christenhusz et al., 2011; Smith et al., 2006). Below, we summarize recent taxonomic and nomenclatural changes and problems that still require further study for Hawaiian fern taxa.

OpHIOGLOSSACEAE.-One example of fern genera in need of further phylogenetic analysis is within the family Ophioglossaceae. The majority of treatments include Sceptridium within the genus Botrychium, and Ophioderma within Ophioglossum (Christenhusz et al., 2011; Smith et al., 2006, 2008). However, a molecular study by Hauk et al. (2003), using plastid DNA sequences from $r b c L$ and $\operatorname{trnL}-F$, showed strong support for the segregation of Sceptridium and Ophioderma as distinct genera. Snow et al. (2011) included Sceptridium within Botrychium and did not address the segregation of Ophioderma. Further phylogenetic analyses are needed to resolve these issues.

BLECHNACEAE.-Another example of uncertain generic boundaries is evident with the circumscription of Blechnum, in which Shepherd et al. (2007) determined Blechnum to be paraphyletic and including Doodia and Sadleria. In accordance with earlier work by Cranfill (2001), Sadleria, an endemic Hawaiian genus, was found nested within Blechnum. However, S. cyatheoides was the only species of the genus included in the study and its placement had only weak support. Christenhusz et al. (2011) accept the genus Sadleria, but state that the status is not clear due to Blechnum being likely paraphyletic. Rothfels et al. (2012b) accept the genus Sadleria based on the inferred phylogeny of Rothfels et al. (2012a). Strong support was found for Doodia as a monophyletic group within Blechnum with B. brasiliense Desv. as the sister species (Shepherd et al., 2007). Further analyses of Doodia are needed before making taxonomic changes because only six of the 15-18 species of Doodia were sampled, including only one of the two Hawaiian endemic species (D. kunthiana). In addition, only one small region of plastid DNA was sequenced (trnL-F) and results differed depending on how the data were analyzed. Furthermore, according to the maximum likelihood tree of Shepherd et al. (2007), Blechnum brasiliense could be placed within Doodia to produce a monophyletic genus. Rothfels et al. (2012b) conserve the genus Doodia, whereas Christenhusz et al. (2011) recognize Doodia within the genus Blechnum. 
ATHYRIACEAE AND CYSTOPTERIDACEAE.-Several recent classifications tentatively place the families Athyriaceae and Cystopteridaceae in Woodsiaceae, which includes four genera found in the Hawaiian Islands: Athyrium, Cystopteris, Deparia, and Diplazium (Smith et al. 2006, 2008; Snow et al., 2011). Molecular work by Schuettpelz and Pryer (2007), using three plastid genes, revealed two members of the Woodsiaceae, Gymnocarpium (not present in the Hawaiian Islands) and Cystopteris, to be paraphyletic and sister to the eupolypods II. Based on these findings, the authors suggested that several families be recognized. Christenhusz et al. (2011) placed both Cystopteris and Gymnocarpium, along with two additional genera, into Cystopteridaceae. The remaining Hawaiian genera (Athyrium, Deparia, and Diplazium), placed within Woodsiaceae as circumscribed by Smith et al. $(2006,2008)$, are included in Athyriaceae by Christenhusz et al. (2011) and Rothfels et al. (2012b). This placement is based on results from several previously published molecular studies (Sano et al., 2000; Schuettpelz and Pryer, 2007; Wang et al., 2003).

NEPHROLEPIDACEAE.-The familial placement of Nephrolepis is unresolved. Kramer (1990) and Palmer (2003) recognized Nephrolepis in its own monogeneric family, Nephrolepidaceae. Smith et al. $(2006,2008)$ tentatively placed the genus within Lomariopsidaceae, which Snow et al. (2011) followed. Recent molecular work using plastid DNA data from three regions revealed strong support for Cyclopeltis and Lomariopsis as sister to Nephrolepis (Hennequin et al., 2010). The authors suggested that Nephrolepis should be treated in its own family, Nephrolepidaceae, until further molecular analyses have been made.

POLYPODIACEAE.-Palmer (2003) recognized three Hawaiian genera of Grammitidaceae: Adenophorus, Grammitis, and Lellingeria. Smith et al. $(2006,2008)$ placed the family within the Polypodiaceae to resolve issues of paraphyly when Grammitidaceae is recognized (i.e., grammitid ferns form a clade that is nested within Polypodiaceae; Schneider et al., 2004b). Molecular and morphological studies have shown strong evidence for Adenophorus as a monophyletic lineage, with Grammitis tenella as the sister taxon to Adenophorus (Ranker et al., 2003, 2004). Based on these findings, Ranker (2008) transferred Grammitis tenella to Adenophorus (A. tenellus).

The remaining grammitid genera that include Hawaiian species, Grammitis and Lellingeria, were found to be polyphyletic (Ranker et al., 2004). Strong support was found for a monophyletic clade within Grammitis (Grammitis sect. Grammitis) that includes the type species of the genus, G. marginella Sw. (Ranker et al., 2004), but none of the Hawaiian species. Species within that clade share the unique character of black, sclerified leaf margins, a character not found in Hawaiian Grammitis (Bishop, 1977; Ranker et al., 2004). In response to those findings as well as from her observations of morphology, Parris (2007) described five new genera, including reestablishing the genus Oreogrammitis, in which she included the three Hawaiian Grammitis species. Preliminary data (Ranker et al., unpublished) based on plastid DNA sequences $r b c L, a t p \beta$, and $\operatorname{trnL}-\operatorname{trn} F$ found there is inadequate information to determine 
the monophyly of Oreogrammitis. Work is in progress to further resolve the generic circumscriptions within Grammitis s. l. (Sundue et al., unpublished). Thus, the placement of the Hawaiian members of Grammitis s. 1. is currently unclear, although the Hawaiian species clearly do not belong to Grammitis s. s. due to the lack of black, sclerified leaf margins. We treat the Hawaiian species here as within Oreogrammitis pending further study.

Ranker et al. (2004) found Lellingeria to be divided into two non-sister clades: one including the L. apiculata (Kunze ex Klotzsch) A. R. Sm. \& R. C. Moran and L. myosuroides (Sw.) A. R. Sm. \& R. C. Moran groups (sister to Melpomene A. R. Sm. \& R. C. Moran) and the other including the L. mitchelliae (Baker) A. R. Sm. \& R. C. Moran group, now called Leucotrichum Labiak, (sister to Alansmia M. Kessler, Moguel, Sundue and Labiak) (Kessler et al., 2011; Rouhan et al., 2012). Lellingeria saffordii, the sole Hawaiian representative, is an endemic species that occurs on all major islands except Ni'ihau and Kaho'olawe. It is nested phylogenetically within the L. myosuroides group, which has recently been described as the new genus Stenogrammitis (Labiak, 2011), and thus the Hawaiian species is treated here as S. saffordii.

PTERIDACEAE.-Ceratopteris is represented in the Hawaiian Islands only by the naturalized species, C. thalictroides, which is found on Kaua'i, O'ahu, and Hawai'i (Imada, 2007; Palmer, 2003). Species in the genus are generally polymorphic and this is especially so with $C$. thalictroides (Masuyama and Watano, 2010). The genus has been variously recognized as including 11 species (e.g., Christensen, 1906), four species (Lloyd, 1974), with Lloyd lumping four previously described species into $C$. thalictroides, and 3 species (Tryon and Tryon, 1982). Masuyama and Watano (2010) proposed that five taxa be segregated from $C$. thalictroides based on differences in the nucleotide sequences of plastid DNA, cytological evidence, and morphological differences (Masuyama et al., 2002; Masuyama and Watano, 2005; Masuyama, 2008). The Ceratopteris found in the Hawaiian Islands included a newly described taxon, C. gaudichaudii var. vulgaris, also known from China, Guam, Japan, Korea, Nepal, and Taiwan (Masuyama and Watano, 2010). Masuyama and Watano (2010) examined two specimens from O'ahu and determined Hawaiian members to be this new variety. Although $C$. gaudichaudii var. vulgaris occurs on O'ahu, it is important to note that additional Ceratopteris taxa may be present in the Hawaiian Islands; further study is needed.

\section{Distribution}

The majority of fern and lycophyte taxa are found on six of the eight main Hawaiian Islands (i.e., Kaua’i, O’ahu, Moloka’i, Lāna’i, Maui, and Hawai'i), with few found on Ni'ihau and Kaho'olawe (Figure 1). Two species, the endemic Doryopteris decipiens and the indigenous Psilotum nudum are distributed on all eight main Hawaiian Islands. [NB: Indigenous is defined here as taxa that are native to a particular area, but are also native elsewhere.] In total there are 140 endemic fern and lycophyte taxa, representing 


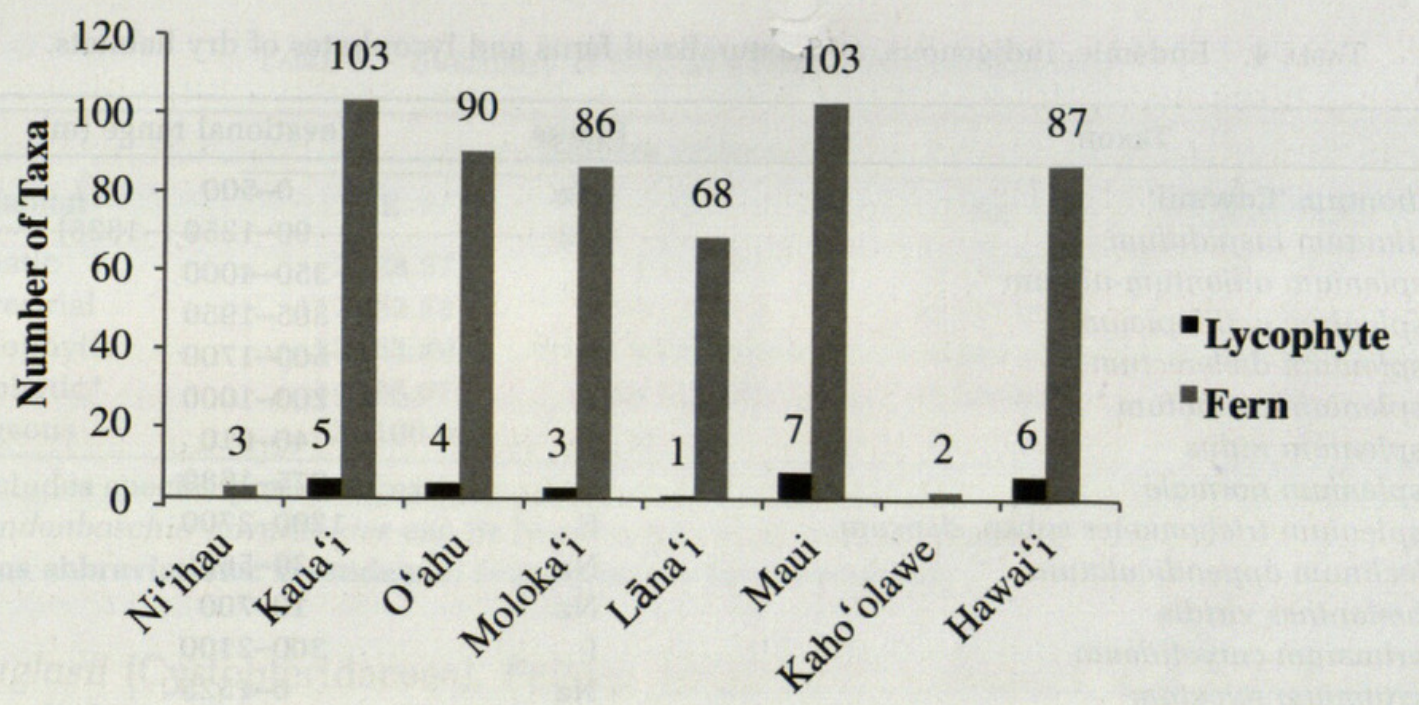

FIG. 2. Endemic fern taxa on each main Hawaiian island. The total taxa per island includes taxa presumed extinct.

approximately $77 \%$ of the 183 native taxa. This level of endemism is high compared to other oceanic islands, which usually have endemic rates of less than $50 \%$ (Moran, 2008). The greatest numbers of endemic fern and lycophyte taxa are found on Kaua'i and Maui (Figure 2). Despite the high level of islandwide endemism, Hawaiian ferns and lycophytes have relatively low numbers of single-island (28 taxa) and two-island (19 taxa) endemics (Figure 3). Only Kaua'i, O'ahu, and Maui have single-island endemics, with Kaua'i harboring the greatest number (17 taxa). The majority of taxa that are restricted to two islands are found on Maui (15 taxa) and Hawai'i (12 taxa).

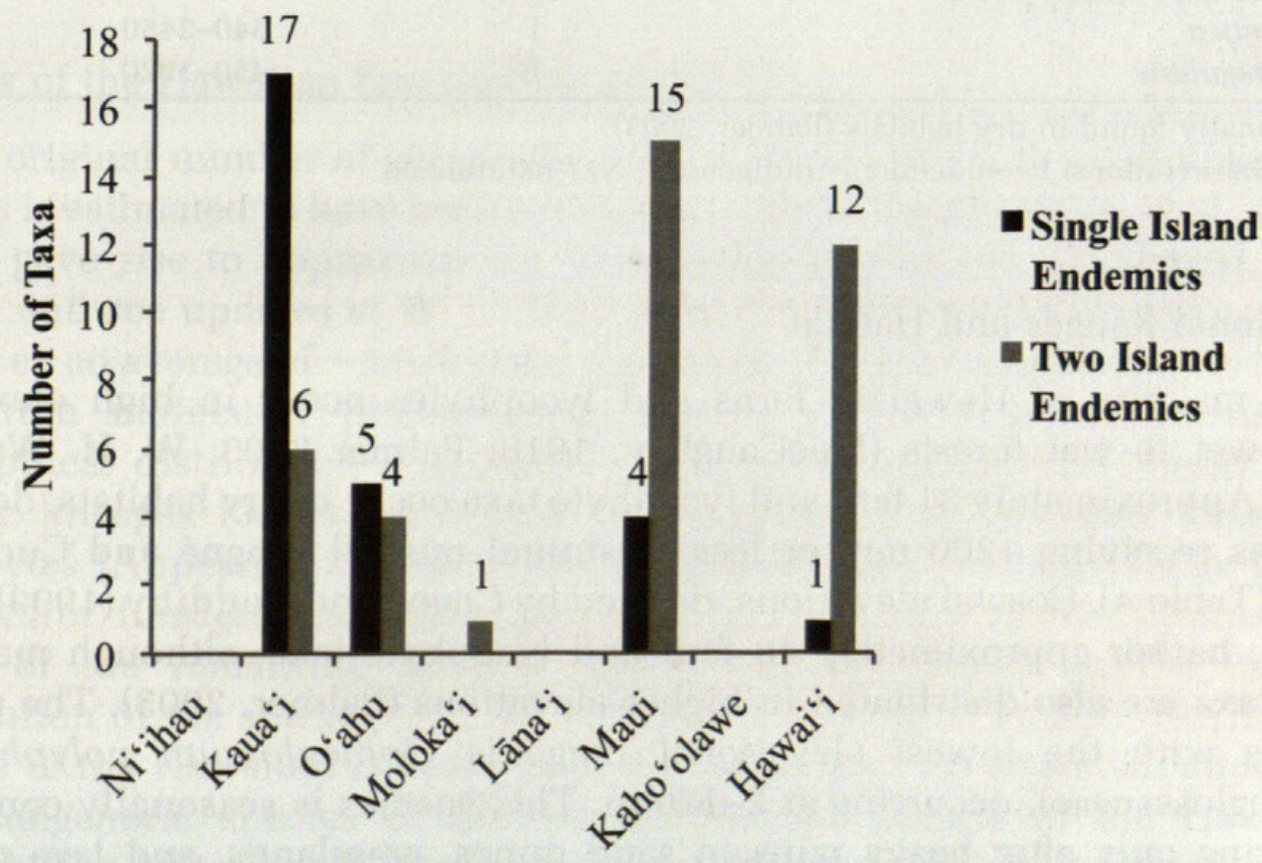

FIG. 3. Distribution of single- and two-island endemics in the eight main Hawaiian Islands. The total taxa per island includes taxa presumed extinct. 
TABLE 4. Endemic, indigenous, and naturalized ferns and lycophytes of dry habitats.

\begin{tabular}{|c|c|c|}
\hline Taxon & Status & Elevational range $(\mathrm{m})$ \\
\hline Adiantum 'Edwinii' & $\mathrm{Nz}$ & $0-500$ \\
\hline Adiantum hispidulum & $\mathrm{Nz}$ & $90-1250(-1825)$ \\
\hline Asplenium adiantum-nigrum & I & $350-4000$ \\
\hline Asplenium aethiopicum * & I & $305-1950$ \\
\hline Asplenium dielerectum & E & $500-1700$ \\
\hline Asplenium caudatum & I & $200-1000$ \\
\hline Asplenium nidus & I & $40-610$ \\
\hline Asplenium normale & I & $375-1680$ \\
\hline Asplenium trichomanes subsp. densum & E & $1200-2700$ \\
\hline Blechnum appendiculatum & $\mathrm{Nz}$ & $30-560$ \\
\hline Cheilanthes viridis & $\mathrm{Nz}$ & $10-700$ \\
\hline Cyrtomium caryotideum & I & $300-2100$ \\
\hline Cyrtomium falcatum & $\mathrm{Nz}$ & $0-1525$ \\
\hline Doodia kunthiana & $\mathrm{E}$ & $90-1220$ \\
\hline Doryopteris decipiens & E & $30-915$ \\
\hline Doryopteris decora & E & $120-700$ \\
\hline Doryopteris takeuchii & $\mathrm{E}$ & $100-120$ \\
\hline Dryopteris fuscoatra var. fuscoatra & $\mathrm{E}$ & $500-2100$ \\
\hline Lepisorus thunbergianus & I & $10-2100$ \\
\hline Lycopodium venustulum var. verticale & E & $1220-2440$ \\
\hline Microlepia speluncae & I & $480-1280$ \\
\hline Microlepia strigosa var. mauiensis & $\mathrm{E}$ & $0-1770$ \\
\hline Microlepia strigosa var. strigosa & I & $425-1830$ \\
\hline Nephrolepis brownii & $\mathrm{Nz}$ & low elevations \\
\hline Pellaea ternifolia & I & $600-3500$ \\
\hline Phlebodium aureum & $\mathrm{Nz}$ & $0-700$ \\
\hline Pityrogramma austroamericana & $\mathrm{Nz}$ & $45-1525$ \\
\hline Pityrogramma calomelanos & $\mathrm{Nz}$ & $0-1000$ \\
\hline Pteris cretica & I & $340-2450$ \\
\hline Pteris irregularis & $\mathrm{E}$ & $450-1920$ \\
\hline
\end{tabular}

*occasionally found in dry habitats (Palmer, 2003)

Status abbreviations: $\mathrm{E}=$ endemic; $\mathrm{I}=$ indigenous; $\mathrm{Nz}=$ naturalized

\section{Elevational Ranges and Habitat}

The majority of Hawaiian ferns and lycophytes occur in high elevation mesic-wet to wet forests (MacCaughey, 1918; Palmer 2003; W. H. Wagner, 1995). Approximately 31 fern and lycophyte taxa occur in dry habitats, defined as areas receiving $1200 \mathrm{~mm}$ or less of annual rainfall (Gagné and Cuddihy, 1999) (Table 4). Coastal elevations, defined by Gagné and Cuddihy (1999) as 0$300 \mathrm{~m}$, harbor approximately 48 fern and lycophyte taxa, although many of these taxa are also distributed in higher elevations (Palmer, 2003). The native species with the lowest elevational range is Ophioglossum polyphyllum (Ophioglossaceae), occurring at $2-160 \mathrm{~m}$. This species is seasonally common, appearing only after heavy rains in sand dunes, grasslands, and lava cobble (Palmer, 2003). Native species that occur at some of the highest elevations (above $3000 \mathrm{~m}$ ) include: Asplenium adiantum-nigrum (Aspleniaceae), Cystopteris 
TABLE 5. Summary of fern and lycophyte taxa habitats ${ }^{1}$.

\begin{tabular}{lcrrr}
\hline & \multicolumn{3}{c}{ Number of taxa (\%) } & \\
\cline { 2 - 4 } \multicolumn{1}{c}{ Habitat } & \multicolumn{1}{c}{$\mathrm{E}$} & $\mathrm{I}$ & $\mathrm{Nz}$ & Total taxa \\
\hline Aquatic & $2(28.57)$ & $1(14.29)$ & $4(57.14)$ & $\mathbf{7}$ \\
Terrestrial & $117(62.23)$ & $39(20.75)$ & $32(17.02)$ & $\mathbf{1 8 8}$ \\
Lithophytic $_{\text {Epiphytic* }}$ & $23(63.89)$ & $9(25.00)$ & $4(11.11)$ & $\mathbf{3 6}$ \\
Epigeous $^{*}$ & $44(66.67)$ & $15(22.73)$ & $7(10.61)$ & $\mathbf{6 6}$ \\
\hline
\end{tabular}

${ }^{1}$ includes species presumed extinct

${ }^{*}$ Vandenboschia davallioides can be hemi-epiphytic as well as epiphytic

Status abbreviations: $\mathrm{E}=$ endemic; $\mathrm{I}=$ indigenous; $\mathrm{Nz}=$ naturalized

douglasii (Cystopteridaceae), Pellaea ternifolia (Pteridaceae), and Polystichum haleakalense (Dryopteridaceae).

The majority of Hawaiian ferns are terrestrial, although many are epiphytic and occur mostly in high elevation, wet forests (Table 5). Several species are restricted to aquatic habitats, including the endangered endemic water clover fern, Marsilea villosa and the rare lycophyte, Isoëtes hawaiiensis (Isoëtaceae). Other interesting habitats include those that are epigeous (growing above, but near the surface of the ground in moss mats at the base of trees) and lithophytic/epipetric (growing on rocks). Only three taxa have an epigeous habit, and all are within the endemic genus Adenophorus: A. epigaeus, A. tamariscinus var. tamariscinus, and A. tripinnatifidus. Several examples of lithophytic species include Asplenium dielerectum, Cyclosorus boydiae, C. pendens, and Doryopteris takeuchii.

\section{Origins of the Hawaiian fern and lycophyte flora}

The original number of colonizing species of angiosperms to the Hawaiian Islands is estimated to have been a minimum of 291 species (Sakai et al., 1995), which gave rise to approximately 1032 native species (W. L. Wagner, pers. comm. and see updates at W. L. Wagner et al., 2005-) in the flowering plant flora (i.e., an average of $\sim 3.6$ derived species per colonizing ancestor). We used data from molecular phylogenetic studies and/or information on the geographical distribution of species and genera to estimate the origins of 78 taxa or lineages (33 endemic and 45 indigenous) of Hawaiian ferns and lycophytes (Appendix 2). Molecular phylogenetic data were available for 22 taxa and/or lineages (see references cited in Appendix 2). We inferred the origin of the remaining 56 taxa and/or lineages based on the current distribution of the species (i.e., for indigenous species of limited distribution outside of the Hawaiian Islands) or of the genus (i.e., for Hawaiian endemics with congeneric species of limited distribution outside of the Hawaiian Islands). The 78 taxa or lineages comprise 103 taxa in total, thus there are an average of $\sim 1.3$ extant taxa per inferred colonizing species (Table 6 and Appendix 2). We estimate that the majority of Hawaiian fern and lycophyte 
TABLE 6. Estimated source regions for the origins of Hawaiian fern and lycophyte lineages ${ }^{1}$.

\begin{tabular}{lccc}
\hline $\begin{array}{l}\text { Distribution of lineage sister } \\
\text { to Hawaiian lineage }\end{array}$ & $\mathrm{E}(\%)$ & $\mathrm{I}(\%)$ & $\mathrm{N}(\%)$ \\
\hline Asia/Paleotropics & $21(64)$ & $25(56)$ & $46(59)$ \\
Neotropics/Americas & $6(18)$ & $5(11)$ & $11(14)$ \\
Boreal & $2(6)$ & $1(2)$ & $3(4)$ \\
Pantropical & $2(6)$ & $10(22)$ & $12(15)$ \\
Cosmopolitan & $1(3)$ & $2(4)$ & $3(4)$ \\
South Pacific & $0(0)$ & $2(4)$ & $2(3)$ \\
Austral & $1(3)$ & $0(0)$ & $1(1)$ \\
Total known/estimated & 33 & 45 & 78 \\
Total unknown & 60 & 0 & 60 \\
\hline
\end{tabular}

${ }^{1}$ includes species presumed extinct

Status abbreviations: $\mathrm{E}=$ endemic; $\mathrm{I}=$ indigenous; $\mathrm{N}=$ native (endemic + indigenous lineages)

lineages (59\%) are of Asian/Paleotropical origin (Table 6); that broad area is the most distant from the Hawaiian Islands compared to other possible source regions. Other hypothesized source regions include Pantropical (15\%, but directionality unknown), Americas/Neotropics (14\%), Cosmopolitan (4\%, but directionality unknown), Boreal (4\%), South Pacific (3\%), and Austral (1\%) (Table 6). Geiger et al. (2007 and references therein) identified four climate- or weather-based phenomena that might allow spores to be carried great distances to the Hawaiian Islands: 1) the northern subtropical jet stream from southeast Asia/Malaysia, 2) northern trade winds from America, 3) tropical storms from Mexico and Central America, and 4) a Hadley Cell shift from the tropical convergence zone that would allow for the Marquesas Islands to be a source area (Geiger et al., 2007; Wright et al., 2001).

Many Hawaiian angiosperm genera are believed to be derived from single colonization events with subsequent diversifications, including the Hawaiian silverswords (Asteraceae), Bidens (Asteraceae), and Schiedea (Caryophyllaceae) (Baldwin and Wagner, 2010). This contrasts with Hawaiian fern genera, which are often the result of multiple colonization events. For example, several biogeographical studies focused on determining the origins of Hawaiian Dryopteridaceae. Geiger and Ranker (2005) used chloroplast DNA (cpDNA) sequences from $r b c L$ and $t r n L-F$ to explore the origins of Hawaiian Dryopteris species. They found Hawaiian Dryopteris to be the result of multiple colonizations and hypothesized five separate colonization events, most of these likely of Southeast Asian origin. In another study of Dryopteridaceae, Driscoll and Barrington (2007) used the same cpDNA sequences as Geiger and Ranker (2005) to explore the origins of Hawaiian Polystichum species. They determined it to be polyphyletic as well, with $P$. hillebrandii being of separate continental eastern Asian origins from the remaining two species, $P$. haleakalense and $P$. bonseyi.

Considerable work also has been conducted to determine the biogeographical origins of the Hawaiian grammitid ferns (Adenophorus, Oreogrammitis (formerly Grammitis, in part), and Stenogrammitis (syn. Lellingeria)). Ranker 
et al. (2004) used cpDNA sequences from $r b c L$ and atp $\beta$ to explore the phylogeny of the grammitid ferns. Their results suggested three colonization events to the Hawaiian Islands. Species of the endemic Hawaiian genus Adenophorus (10 spp.) were hypothesized to have originated from a single Neotropical ancestor and further analyses from Geiger et al. (2007) provided additional support for this hypothesis. The origins of Hawaiian Oreogrammitis (3 spp.) are unclear. Ranker et al. (2004) postulated a southwest Pacific origin based on the sister relationship of $O$. knutsfordiana (Baker) Parris to the Hawaiian Oreogrammitis clade. Geiger et al. (2007) further supported this hypothesis, but the exact origins of the Hawaiian clade are unknown due to the widespread distribution of $O$. knutsfordiana. The third genus of Hawaiian grammitids, Stenogrammitis (1 sp.), is believed to be of Neotropical origin. Geiger et al. (2007) determined the Hawaiian species $S$. saffordii to be sister to $S$. subcoriacea (Copel.) Labiak from the Marquesas and Society Islands. Because this clade is sister to the Neotropical species $S$. limula, they hypothesized a Neotropical origin for the Hawaiian Stenogrammitis. A recent study by Labiak et al. (2010) suggests a Neotropical origin, but provided support for $S$. saffordii as being sister to the Mexican species $S$. hellwigii (Mickel \& Beitel) Labiak.

Multiple colonizations like those for the Dryopteridaceae also have been postulated for Hawaiian Doryopteris (Yesilyurt, 2005) and the indigenous Asplenium adiantum-nigrum (Ranker et al., 1994; Shivas, 1969). According to Yesilyurt (2005) there are molecular data (Yesilyurt et al. in prep) that suggest $D$. decora and $D$. decipiens are the result of separate introductions to the Hawaiian Islands. Another Hawaiian fern, the aquatic Marsilea villosa, has been hypothesized to be of North American ancestry. Nagalingum et al. (2007) used six plastid regions to determine strong support for $M$. villosa as being sister to M. oligospora Goodd. and M. vestita Hook. \& Grev., both North American temperate species. Molecular work by Whitten et al. (2012) found additional support for a North American origin. Shivas (1969) hypothesized Asplenium adiantum-nigrum to be of hybrid origin from two diploid European taxa based on cytological data. Ranker et al. (1994) used isozyme data to infer multiple colonization events of this species to the Hawaiian Islands.

\section{Conservation of Hawaiian Ferns}

Conservation of the Hawaiian flora and preservation of the native forests is of most immediate concern in the Hawaiian Islands. Extinction rates within the United States are highest in the Hawaiian Islands (Gagné, 1988). Despite this high level of extinction, only three historically documented fern species and one lycophyte species are presumed to be extinct in the Hawaiian Islands (Table 7). The primary threat to the decline of Hawaiian ferns and lycophytes is habitat destruction by humans and feral animals (Given, 1993; W. H. Wagner, 1995). Habitat destruction of the Hawaiian Islands began with the Polynesian settlers, but increased rapidly after Western contact (Gagné, 1988). The introduction of feral animals (e.g., pigs, sheep, cattle, deer, goats) and 
TABLE 7. Federal and state status of Hawaiian ferns and lycophytes.

\begin{tabular}{|c|c|c|c|c|c|c|}
\hline \multirow{3}{*}{$\frac{\text { Taxon }}{\text { Adenophorus periens ** }}$} & \multirow[b]{2}{*}{$\begin{array}{c}\text { Date Federally } \\
\text { Listed }\end{array}$} & \multicolumn{5}{|c|}{ Status } \\
\hline & & $\mathrm{X}$ & $\mathrm{E}$ & $\mathrm{C}$ & SC & SGCN \\
\hline & $11 / 10 / 1994$ & & $\mathrm{x}$ & & & $\mathrm{x}$ \\
\hline Asplenium dielerectum ** & $11 / 10 / 1994$ & & $\mathrm{x}$ & & & $\mathrm{x}$ \\
\hline Asplenium dielfalcatum & $10 / 29 / 1991$ & & $\mathrm{x}$ & & & $\mathrm{x}$ \\
\hline Asplenium dielmannii ** & $05 / 13 / 2010$ & & $\mathrm{x}$ & & $\mathrm{x}$ & $\mathrm{x}$ \\
\hline Asplenium dielpallidum ** & $02 / 25 / 1994$ & & $\mathrm{x}$ & & & $\mathrm{x}$ \\
\hline Asplenium leucostegioides & - & $\mathrm{x}$ & & & $\mathbf{x}$ & \\
\hline Asplenium peruvianum var. insulare ** & $09 / 26 / 1994$ & & $\mathrm{x}$ & & & $\mathrm{x}$ \\
\hline Asplenium schizophyllum & - & & & & $\mathrm{x}$ & \\
\hline Asplenium unisorum & $06 / 27 / 1994$ & & $\mathrm{x}$ & & & $\mathrm{x}$ \\
\hline Athyrium microphyllum * & - & & & & & $\mathrm{x}$ \\
\hline Cibotium chamissoi * & - & & ( & & & $\mathrm{x}$ \\
\hline Cibotium glaucum * & - & & se & & & $\mathrm{x}$ \\
\hline Cibotium spp. & - & & & & & $x$ \\
\hline Ctenitis squamigera & $09 / 26 / 1994$ & & $\mathrm{x}$ & & & $\mathrm{x}$ \\
\hline Cyclosorus boydiae & - & & & $\mathrm{x}$ & & \\
\hline Cyclosorus interruptus * & - & & & & & $\mathrm{x}$ \\
\hline Cyclosorus wailele & - & & & & $\mathrm{x}$ & \\
\hline Cystopteris douglasii & - & & & & $\mathrm{x}$ & \\
\hline Deparia kaalaana & - & $\mathrm{x}$ & & & $x$ & \\
\hline Dicranopteris linearis * & - & & & & & $\mathrm{x}$ \\
\hline Diplazium molokaiense ** & $09 / 26 / 1994$ & & $x$ & & & $\mathrm{x}$ \\
\hline Diplazium sandwichianum * & - & & & & & $\mathrm{x}$ \\
\hline Doryopteris angelica ** & $05 / 13 / 2010$ & & $\mathrm{x}$ & & & $x$ \\
\hline Doryopteris takeuchii & $09 / 18 / 2012$ & & $\mathrm{x}$ & & & \\
\hline Dryopteris crinalis var. podosora ** & $05 / 13 / 2010$ & & $\mathrm{x}$ & & $\mathrm{x}$ & $x$ \\
\hline Dryopteris tetrapinnata & - & & & & $x$ & $\mathrm{x}$ \\
\hline Dryopteris spp. & - & & & & & $x$ \\
\hline Elaphoglossum spp. & - & & & & & \\
\hline Huperzia haleakalae ${ }^{* \star *}$ & - & $\mathbf{x}$ & & & & \\
\hline Huperzia mannii & $05 / 15 / 1992$ & & $\mathrm{x}$ & & & $\mathrm{x}$ \\
\hline Huperzia nutans & $03 / 28 / 1994$ & & $\mathrm{x}$ & & & $\mathrm{x}$ \\
\hline Huperzia stemmermanniae ** & - & & & $\mathbf{x}$ & & $\mathrm{x}$ \\
\hline Isoetes hawaiiensis & - & & & & $\mathrm{x}$ & \\
\hline Marsilea villosa * & $06 / 22 / 1992$ & & $\mathrm{x}$ & & & $\mathrm{x}$ \\
\hline Microlepia strigosa var. mauiensis & - & & & $x$ & & $\mathrm{x}$ \\
\hline Pteris lidgatei ** & $09 / 26 / 1994$ & & $\mathrm{x}$ & & & $x$ \\
\hline Sadleria cyatheoides * & - & & & & & $\mathbf{x}$ \\
\hline Sceptridium subbifoliatum & - & $\mathrm{x}$ & & & $\mathbf{x}$ & \\
\hline
\end{tabular}

* important component of native habitat (Mitchell et al., 2005)

** fewer than 50 individuals in the wild (PEP, 2011)

*** extant elsewhere, extinct only in the Hawaiian Islands (W. L. Wagner et al., 2005-)

Status designation: $\mathrm{X}=$ extinct (Wagner et al., 2005-); $\mathrm{E}=$ endangered (USFWS, 2012a; 2012b); $\mathrm{C}=$ candidate (USFWS, 2012b); $\mathrm{SC}=$ species of concern (DOFAW, 2001); SGCN = species of greatest conservation need (Mitchell et al., 2005) 
non-native plant species has further contributed to the habitat loss and population decline in Hawaiian ferns (W. H. Wagner, 1995).

Approximately 1366 non-native vascular plant species have been introduced to the Hawaiian Islands and have since become naturalized (C. Imada, pers. comm. and W. L. Wagner et al., 2012). These plants were introduced to the Hawaiian Islands primarily for their use in the horticultural trade, although some introductions were accidental. Non-native, alien taxa have the potential to become naturalized and possibly invasive by competing with the native flora. Over 260 species of cultivated alien ferns are estimated to have been introduced to the Hawaiian Islands mainly for the horticultural trade and use in botanical gardens (Robinson et al., 2010; Wilson, 1996). The most recent publications (Palmer, 2003; Wilson, 2002) report 33 naturalized fern and lycophyte taxa, all of which were likely introduced to the islands after 1880 (Wilson, 2002). As stated above, since Palmer (2003) was published, seven new fern taxa have been reported as naturalized in the state (Table 3).

Single, invasive fern species have caused major problems in many parts of the world (Robinson et al., 2010). By contrast, at least 18 species in the Hawaiian Islands have become invasive based on their abundance and widespread distribution throughout the islands (Palmer, 2003). Invasive species often are highly detrimental to native ecosystems due to their ability to outcompete and displace the native flora. For example, the introduced tree fern Sphaeropteris cooperi (Cyatheaceae) grows faster and produces more leaves than the native tree ferns, Cibotium spp. (Cibotiaceae) (Durand and Goldstein, 2001). Another example is of the common, naturalized fern Blechnum appendiculatum, reported as one of the two plants completely overgrowing a population of the endangered fern Asplenium dielpallidum (Aguraiuja et al., 2004).

Several naturalized fern species hybridize with native Hawaiian species. For example, the naturalized fern Cyclosorus dentatus has crossed with the endemic species Cyclosorus cyatheoides (Cyclosorus $\times$ palmeri (W. H. Wagner) W. H. Wagner) on Kaua'i and O'ahu (W. H. Wagner et al., 1999). Another example is of an intergeneric hybrid ( $\times$ Lindsaeosoria flynnii W. H. Wagner), the naturalized Lindsaea ensifolia (Lindsaeaceae) crossing with the indigenous Sphenomeris chinensis (Lindsaeaceae) (W. H. Wagner, 1993). The effects of naturalized species crossing with native species are not entirely known, although these hybrids have the potential to threaten native biodiversity due to the effects of outbreeding depression and introgression (Bleeker et al., 2007).

Many Hawaiian endemic ferns are difficult to cultivate, likely because of their requirement of highly specialized habitats (W. H. Wagner, 1995). Examples of this are ferns with green spores (grammitid ferns and Hymenophyllaceae) that germinate immediately, given the proper environmental factors (Mehltreter, 2010). However, if proper environmental conditions are not met, the chlorophyll in the spores can quickly break down, and viability of the spores may be reduced to approximately seven weeks (Mehltreter, 2010). Propagation of these ferns can be difficult and expensive due to the need for specific environmental conditions that are not always 


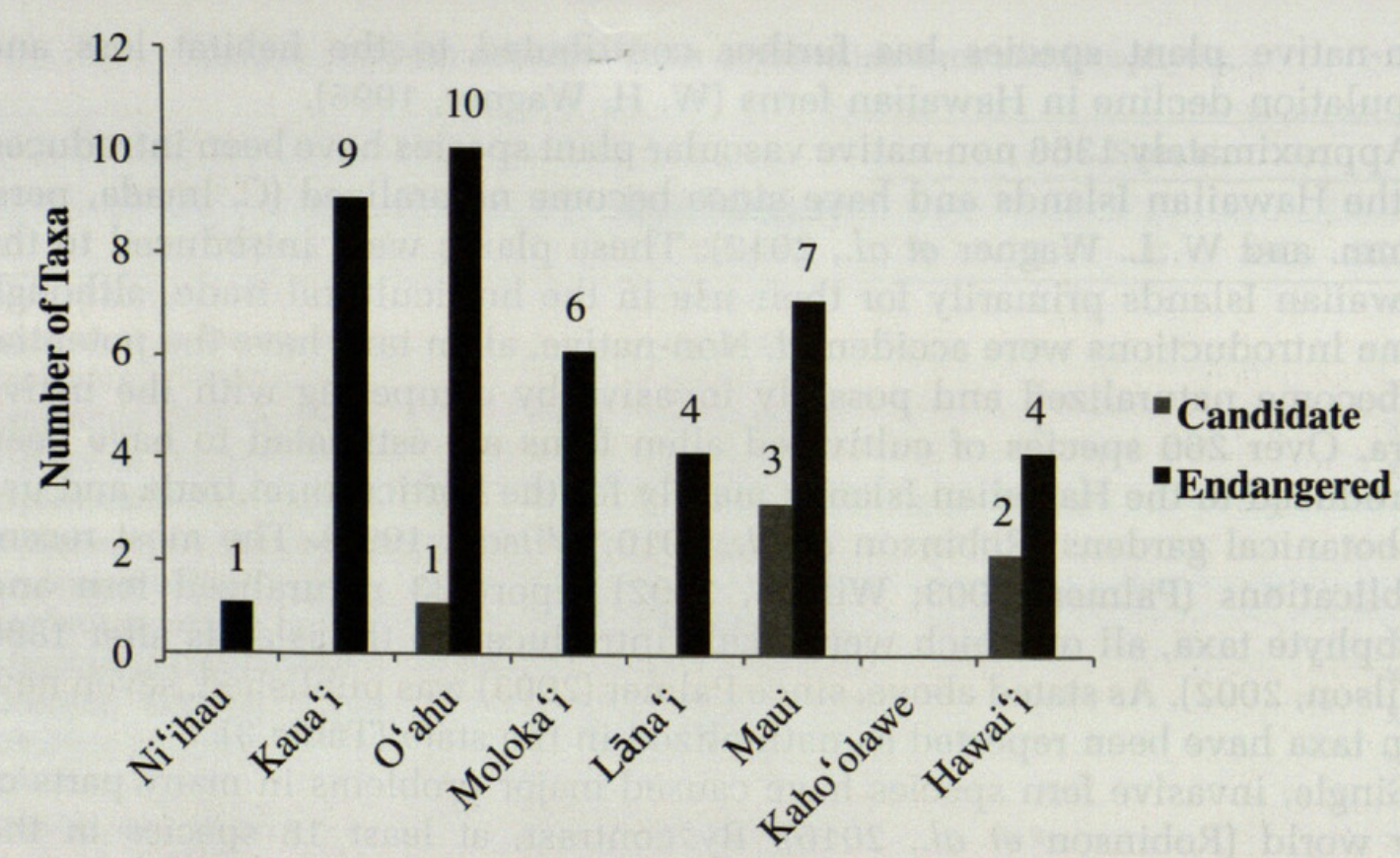

FIG. 4. Federally listed endangered, proposed, and candidate taxa on each of the main Hawaiian Islands. The total taxa per island includes taxa presumed extinct.

achievable in the traditional greenhouse settings (W. H. Wagner, 1995). It is therefore critical that these species are identified so accurate environmental assessments are documented and land be preserved that can host these endemic species.

\section{Endangered Hawaiian Ferns}

As of 2012, the U. S. Fish and Wildlife Service had listed 339 Hawaiian plant taxa as either threatened ( 9 taxa) or endangered (330 taxa). Of those, $5 \%$ are ferns (14 taxa) and lycophytes (2 taxa) and all are listed as endangered (Table 7). Doryopteris takeuchii, a fern endemic to Diamond Head Crater on O'ahu, was recently listed as endangered (USFWS, 2012a). In addition, three taxa are candidate species: Cyclosorus boydiae, Microlepia strigosa var. mauiensis, and Huperzia stemmermanniae (Lycopodiaceae). The greatest number of federally listed (including endangered and candidate taxa) ferns and lycophytes occur on O'ahu, although Kaua'i and Maui have nearly the same number (Figure 4). One taxon, Dryopteris glabra var. pusilla, was formerly listed as a candidate species, but has been removed due to the likelihood that the species has a greater distribution than previously thought; additional surveys are needed (USFWS, 2004).

The Hawai'i Department of Fish and Wildlife (DOFAW, 2001) identified nine fern taxa and one lycophyte as "species of concern" and in greatest need of conservation efforts (Table 7). W. L. Wagner et al. (2005-) consider three of these to be extinct (i.e., Asplenium leucostegioides, Deparia kaalaana, and Sceptridium subbifoliatum (Ophioglossaceae)) and two are currently federally listed as endangered (Asplenium dielmannii and Dryopteris crinalis var. podosora). 
TABLE 8. Reported individuals of federally listed endangered Hawaiian ferns and lycophytes in wild populations.

\begin{tabular}{lcl}
\hline \multicolumn{1}{c}{ Taxon } & Reported individuals & \multicolumn{1}{c}{ Reference } \\
\hline Adenophorus periens & $15-123$ & USFWS, 2010a \\
Asplenium dielerectum & $<100$ & USFWS, 2009c \\
Asplenium dielfalcatum & thousands & USFWS, 2011a \\
Asplenium dielmannii & $\sim 60$ & K. Wood, pers. comm. \\
Asplenium dielpallidum & 12 & USFWS, 2008 \\
Asplenium peruvianum var. insulare & 278 & USFWS, 1998 \\
Asplenium unisorum & 1148 & USFWS, 2011b \\
Ctenitis squamigera & $234-242$ & USFWS, 2009d \\
Diplazium molokaiense & $\sim 65$ & USFWS, 2010b \\
Doryopteris angelica & $29-54$ & USFWS, 2011c \\
Doryopteris takeuchii & $50-100$ & USFWS, 2012a \\
Dryopteris crinalis var. podosora & $32-47$ & USFWS, 2011d \\
Huperzia mannii & $61-71$ & USFWS, 2011e \\
Huperzia nutans & 11 & USFWS, 2009e \\
Marsilea villosa & thousands & USFWS, 2011f \\
Pteris lidgatei & 51 & USFWS, 2009b \\
\hline
\end{tabular}

In 2005, DOFAW and the Division of Aquatic Resources (DAR) within the Department of Land and Natural Resources (DLNR) developed a Comprehensive Wildlife Conservation Strategy (CWCS) to review the status of the native terrestrial and aquatic species in the Hawaiian Islands (Mitchell et al., 2005). The CWCS identifies the Hawaiian species of greatest conservation need (SGCN) and provides strategic plans for their conservation. The criteria CWCS used to determine a SGCN need may be found at: http://www.state.hi.us/ dlnr/dofaw/cwcs/process_strategy.htm. The CWCS includes 22 ferns and 3 lycophytes as species of greatest conservation need (Table 7). Eight of these species are listed as SGCN because they play an important role in their native habitats as either a dominant member of the native plant community or by hosting or providing habitat for other native species (Mitchell et al., 2005). Along with these species, three genera (Cibotium, Dryopteris, and Elaphoglossum) also have this designation (Mitchell et al., 2005).

The Plant Extinction Prevention (PEP) program of Hawai'i reported nine fern taxa and one lycophyte with less than 50 individuals remaining in wild populations: Adenophorus periens, Asplenium dielerectum, A. dielmannii, A. dielpallidum, Asplenium peruvianum var. insulare, Diplazium molokaiense, Doryopteris angelica, Dryopteris crinalis var. podosora, Huperzia stemmermanniae, and Pteris lidgatei (PEP, 2011). Approximate numbers of currently known individuals of endangered Hawaiian ferns have been compiled from reports of the USFWS and additional resources (Table 8).

\section{Extinct Hawaiian Ferns}

W. L. Wagner et al. (2005-) reported three ferns and one lycophyte from the Hawaiian Islands as extinct (Table 7). A single plant of one previously 
believed extinct species (HBS, 1999), Asplenium dielmannii (syn. Diellia mannii), was rediscovered on Kaua'i in 2003 (Aguraiuja and Wood, 2003). Prior to this discovery, the last known collections were made in western Kaua'i sometime between 1871 and 1886 (Aguraiuja and Wood, 2003). There have been further discoveries of this species on the island of Kaua'i. Another population of approximately 60 individuals was discovered in 2010 and a fence was built around the population for protection (K. Wood, pers. comm.). No additional rediscoveries of presumed extinct ferns have been reported, but it is difficult, if not impossible, to know with certainty when a species is definitely extinct. As Palmer (2003) suggested, the presumed extinct fern, Sceptridium subbifoliatum, may be overlooked in the field due to the similarity of its young leaves to those of Marattia douglassii (Marattiaceae).

Hawaiian ferns and lycophytes are important components in native Hawaiian ecosystems and it is therefore necessary that these plants be bettered understood and protected. We hope this publication along with the interactive key will evoke interest and further educate those interested in Hawaiian ferns and lycophytes.

\section{ACKNOWLEDGMENTS}

This research was supported by the University of Hawai'i at Mānoa. Additional funding was generously provided from the Charles H. Lamoureux Fellowship and the Graduate Student Organization at the University of Hawai'i at Mānoa. We are especially grateful to Alan R. Smith and Daniel Palmer for their valuable assistance with the preparation of the manuscript. Tim Flynn, John Game, David H. Lorence, Warren L. Wagner, and Ken R. Wood also provided valuable comments. Cliff Morden and Neil Snow greatly contributed to the initial development of this paper. We thank the staff of the following herbaria for providing access to the collections: BISH, HAW, and PTBG. Thank you to all who contributed images for the interactive key including Tom Ballinger, Marian Chau, Heather Driscoll, Danielle Frohlich, John Game, Edy Horwood, Kapua Kawelo, Alex Lau, David Lorence, Robbin Moran, Shane Shaw, Forest \& Kim Starr, Anna Stone, Tiffany Thair, Daniella Thompson, and Ken Wood and to Matt Taylor and Michael Thomas for their technical support. Thank you to Kay Lynch of La'au Hawai'i for providing specimens to photograph.

\section{LiterATURE CITED}

Aguraiuja, R. and K. R. Wood. 2003. Diellia mannii (D. C. Eaton) Robins. (Aspleniaceae) Rediscovered in Hawaii. Am. Fern J. 93:154-156.

Aguraiuja, R., M. Moora and Zobel. 2004. Population stage structure of Hawaiian endemic fern taxa of Diellia (Aspleniaceae): implications for monitoring and regional dynamics. Canad. J. Bot. 82:1438-1445.

Alan, H. H. 1982. Flora of New Zealand, Vol 1. Indigenous Tracheophyta-Psilopsida, Lycopsida, Filicopsida, Gymnospermae, Dicotyledons. P. D. Hasselberg Government Printer, Wellington.

Balley, E. 1883. Hawaiian Ferns: A Synopsis. Thos. G. Thrum, Honolulu.

BALDWIN, B. G. and W. L. WAGNER. 2010. Hawaiian angiosperm radiations of North American origin. Ann. Bot.-London. 105:849-879.

Bishop, L. E. 1977. The American species of Grammitis Sect. Grammitis. Am. Fern J. 67:101-106. BLEEKER, W., U. SCHMITZ and M. RISTOW. 2007. Interspecific hybridization between alien and native plant species in Germany and its consequences for native biodiversity. Biol. Conserv. 137:248-253. 
Brackenridge, W. D. 1971. Atlas. Botany. Cryptogamia. Filices, including Lycopodiaceae and Hydropterides. Weinheim, J. Cramer, New York. (Original work published 1855).

Brownlie, G. 1977. The Pteridophyte Flora of Fiji. J. Cramer, New York.

Chambers, T. C. and P. A. FARrant. 2001. Revision of Blechnum (Blechnaceae) in Malesia. Blumea 46:283-350.

Chiou, W., W. Shieh and C. E. Devol. 1994. Flora of Taiwan. 2nd ed. Vol. 1. Pteridophyta Gymnospermae. Editorial Committee of the Flora of Taiwan, Taipei, Taiwan, Republic of China.

Christenhusz, M. J. M., X.-C. Zhang and H. Schneider. 2011. A linear sequence of extant families and genera of lycophytes and ferns. Phytotaxa. 19:7-54.

Christensen, C. 1906. Index Filicum. H. Hagerup, Copenhagen.

Christensen, C. 1925. Revised List of Hawaiian Pteridophyta. Bull. Bernice P. Bishop Mus. 25.

Copeland, E. B. 1914. Hawaiian ferns collected by M. L'abbé U. Faurie. Philipp. J. Sci., C 9:435-441.

Copel.and, E. B. 1916. Hawaiian ferns collected by J. F. Rock. Philipp. J. Sci., C 11:171-173.

CRANFILL, R. B. 2001. Phylogenetic studies in the Polypodiales (Pteridophyta) with an emphasis on the family Blechnaceae. Unpublished $\mathrm{PhD}$ thesis, University of California, Berkeley, California, USA.

Degener, O. and I. Degener. 1932-1980. Flora Hawaiiensis or New illustrated flora of the Hawaiian Islands. Published privately, Honolulu.

Der, J. P., J. A. Thomson, J. K. Stratford and P. G. Wolf. 2009. Global chloroplast phylogeny and biogeography of bracken (Pteridium: Dennstaedtiaceae). Am. J. Bot. 96:1441-1449.

Derby, C. 1875. List of Hawaiian ferns, compiled expressly for this annual. Thrum's Hawaiian Annual 1:16-18.

[DOFAW] Hawail Division of Forestry and WildLife. 2001. List of Threatened and Endangered Plants in Hawaii. http://www.state.hi.us/dlnr/dofaw/pubs/TEplant.html [accessed April 2011].

Driscoll, H. E. and D. S. BARRIngton. 2007. Origin of Hawaiian Polystichum (Dryopteridaceae) in the context of a world phylogeny. Am. J. Bot. 94:1413-1424.

Durand, L. K. and G. Goldstein. 2001. Photosynthesis, photoinhibition, and nitrogen use efficiency in native and invasive tree ferns in Hawaii. Oecologia 126:345-354.

Ebihara, A., S. Hennequin, K. Iwatsuki, P. Bostock, S. Matsumoto, R. Jaman, J.-Y. Dubuisson and M. ITo. 2004. Polyphyletic origin of Microtrichomanes (Mett. Ex Prantl) Copel. (Hymenophyllaceae) with a revision of the species. Taxon 53:935-948.

Fowler, R. L. 1940. Annotated list of ferns of the Kilauea-Mauna Loa Section of Hawaii National Park. Am. Fern J. 30:9-18.

Frohlich, D. and A. Lau. 2008. New Plant Records from Oahu for 2007. Bishop Mus. Occ. Pap. 100:3-12.

GAGNÉ, W. C. 1998. Conservation priorities in Hawaiian natural systems: increased public awareness and conservation action are required. BioScience 38:264-271.

Gagné, W. C., W. Cuddihy. 1999. Vegetation. Pp. 45-114, in Wagner, W. L., DerralR. Herbst and S. H. SOHMER. 1999. Manual of the Flowering Plants of Hawaii. Revised edition with supplement. University of Hawaii Press, Honolulu.

Gaudichaud, C. 1826. Botanique du Voyage autour du monde. Chez Pillet Aine, Paris.

Geiger, J. M. O. and T. A. RANKER. 2005. Molecular phylogenetics and historical biogeography of Hawaiian Dryopteris (Dryopteridaceae). Mol. Phylogenet. Evol. 34:392-407.

Geiger, J. M. O, T. A. RanKer, J. M. Ramp Neale and S. T. Klimas. 2007. Molecular biogeography and origins of the Hawaiian fern flora. Brittonia 59:142-158.

GIVEN, D. R. 1993. Changing aspects of endemism and endangerment in pteridophyta. J Biogeogr. 20:293-302.

Hassler, M. and B. Swale. 2003. Checklist of World Ferns on CD-ROM. Distributed by the authors.

[HBS] HawaII Biological SuRvey. 1999. Hawaii's extinct species-plants. http://hbs.bishopmuseum. org/endangered/ext-plants.html [accessed April 2011].

HAUFLER, C. H. and T. A. RANKER. 1995. rbcL sequences provide phylogenetic insights among sister species of the fern genus Polypodium. Am. Fern J. 85:361-374.

Hauk, W. D, C. R. PARKS and M. W. Chase. 2003. Phylogenetic studies of Ophioglossaceae: evidence from $r b c L-F$ plastid DNA sequences and morphology. Molec. Phylogen. Evol. 28:131-151. 
HeLler, A. A. 1897. Observations on the ferns and flowering plants of the Hawaiian Islands. Minnesota Bot. Stud. 1:760-922.

Hennequin, S., A. Ebihara, M. Ito, K. Iwatsuki and J.-Y. Dubuisson. 2003. Molecular systematics of the fern genus Hymenophyllum s.l. (Hymenophyllaceae) based on chloroplastic coding and noncoding regions. Mol. Phylogenet. Evol. 27:283-301.

Hennequin, S., A. Ebihara, M. Ito, K. Ifatsuki and J.-Y. Dubuisson. 2006. New insights into the phylogeny of Hymenophyllum (Hymenophyllaceae): revealing the polyphyly of Mecodium. Syst. Bot. 31:271-284.

Hennequin, S., P. Hovenkamp, M. J. M. Christenhusz and H. Schneider. 2010. Phylogenetics and biogeography of Nephrolepis-a tale of old settlers and young tramps. Bot. J. Linn. Soc. 164:113-127.

Hoot, S. B., W. C. TAYLOR and N. S. NAPIER. 2006. Phylogeny and biogeography of Isoëtes (Isoëtaceae) based on nuclear and chloroplast DNA sequence data. Syst. Bot. 31:449-460.

Hovenkamp, P. H. 1986. A monograph of the fern genus Pyrrosia. (Polypodiaceae). E. J. Brill/Leiden University Press (Leiden Bot. Ser., vol. 9), Leiden.

HubBard, D. H. 1952. Ferns of Hawaii National Park. Hawaii Nat. Notes. 5:1-40.

IMADA, C. T. 2007. New Hawaiian plant records for 2005-2006. Bishop Mus. Occ. Pap. 96:34-41.

IMADA, C. T. 2008. Hawaiian flowering plants checklist: "Main Hawaiian Islands". Unpublished, available at: http://www.bishopmuseum.org/research/natsci/botany/dband-keys/Main\% 20 Islands\%20Report.pdf. [accessed March 2010].

Jacona, C. C. and D. M. Johnson. 2006. Water-clover ferns, Marsilea, in the Southeastern United States. Castanea. 71:1-14.

JoHnson, D. M. 1986. Systematics of the New World species of Marsilea (Marsileaceae). Syst. Bot. Monogr. 11:1-87.

Kato, M. 2001. Deparia cataracticola (Woodsiaceae), a new species from Hawaii. Acta. Phytotax. Geobot. 52:1-9.

KenNEDY, B. H., S. A. JAMES and C. T. IMADA. 2010. New Hawaiian plant records from Herbarium Pacificum for 2008. Bishop Mus. Occ. Pap. 107:19-26.

KeSSLER, M. 2010. Biogeography of ferns. Pp. 22-60 in Mehltreter, K., L. R. Walker and J. M. Sharpe, eds. Fern Ecology. Cambridge University Press, Cambridge.

Kesslerm, A. L. M. Velazquez, M. Sundue and P. H. Labiak. 2011. Alansmia, a new genus of grammitid ferns (Polypodiaceae) segregated from Terpsichore. Brittonia 63:233-244.

KRAMER, K. U. 1990. Nephrolepidaceae. Pp. 188-190 in Kramer, K. U. and P. S. Greene, eds. The Families and Genera of Vascular Plants Vol. 1. Pteridophytes and Gymnosperms. Springer, Berlin.

Kramer, K. U. and P. M. McCarthy. 1998. Flora of Australia, Australian Biological Resources Study. Vol 48. Flora of Australia: Ferns, gymnosperms and allied groups. CSIRO, Australia.

Kreier, H.-P., X.-C. Zhang, H. Muth and H. Schneider. 2008. The microsoroid ferns: Inferring the relationships of a highly diverse lineage of Paleotropical epiphytic ferns (Polypodiaceae, Polypodiopsida). Molec. Phylogenet. Evol. 48:1155-1167.

LABIAK, P. H., M. SunduE and G. RouHAN. 2010. Molecular phylogeny, character evolution, and biogeography of the grammitid fern genus Lellingeria (Polypodiaceae). Am. J. Bot. 97:1354-1364.

LabIaK, P. H. 2011. Stenogrammitis, a new genus of grammitid ferns segregated from Lellingeria (Polypodiaceae). Brittonia 63:139-149.

LaU, A. and Frohlich, D. 2012. New Plant Records from O'ahu for 2009. Bishop Mus. Occ. Pap. 113:7-26.

LLoyd, R. M. 1974. Systematics of the genus Ceratopteris Brogn. (Pakeriaceae) II. taxonomy. Brittonia 26:139-160.

LORENCE, D. H. and T. FLYNN. 2006. New naturalized plant records for Kauai and Hawaii. Bishop Mus. Occ. Pap. 88:1-5.

Lydgate, J. M. 1873. A Short Synopsis of Hawaiian Ferns. publisher unknown. Honolulu.

Lyons, A. B. 1890. Artificial Key to the Genera and Species of Hawaiian Ferns. Press Publishing Company Print, Honolulu.

MacCaughey, V. 1918. An ecological survey of the Hawaiian pteridophytes. J. Ecol. 6:199-219. 
Masuyama, S. 2008. Cryptic species in the fern Ceratopteris thalictroides (L.) Brongn. (Parkeriaceae). III. referential diagnostic characters of three cryptic species. J. Plant Res. 121:279-286.

Masuyama, S. and Y. Watano. 2010. Cryptic species in the fern Ceratopteris thalictroides (L.) Brongn. (Parkeriaceae). IV. taxonomic revision. Acta. Phytotax. Geobot. 61:75-86.

Masuyama, S., Y. Yatabe, N. Murakami and Y. Watano. 2002. Cryptic species in the fern Ceratopteris thalictroides (L.) Brongn. (Parkeriaceae). I. molecular analyses and crossing tests. J. Plant Res. 115:87-97.

Masuyama, S. and Y. Watano. 2005. Cryptic species in the fern Ceratopteris thalictroides (L.) Brongn. (Parkeriaceae). II. cytological characteristics of three cryptic species. Acta. Phytotax. Geobot. 56:231-240.

Mehltreter, K. 2010. Fern Conservation. Pp. 323-359 in Mehltreter, K., L. R. Walker and J. M. Sharpe, eds. Fern Ecology. Cambridge University Press, Cambridge.

Mitchell, C., C. Ogura, D. Meadows, A. Kane, L. Strommer, S. Fretz, D. Leonard and A. McClung. 2005. Hawaii's Comprehensive Wildlife Conservation Strategy. Department of Land and Natural Resources, Honolulu, Hawaii.

Moran, R. C. 2008. Diversity, biogeography, and floristics. Pp. 367-394 in Ranker, T. A. and C. H. Haufler, eds. Biology and Evolution of Ferns and Lycophytes. Cambridge University Press, Cambridge.

Morton, C. V. 1957. Observations on cultivated ferns, IV. the species of Davallia. Am. Fern J. 47:143-148.

MuRDOCK, A. G. 2008. Phylogeny of marattioid ferns (Marattiaceae) inferring a root in the absence of a closely related outgroup. Am. J. Bot. 95:626-641.

NAGALINGUM, N. S., H. SCHNEIDER and K. M. PRYER. 2007. Molecular phylogenetic relationships and morphological evolution in the heterosporous fern genus Marsilea. Syst. Bot. 32:16-25.

NoотевоOм, H. P. 1994. Notes on Davalliaceae II. A revision of the genus Davallia Blumea 39:151-214.

ØllgaARD, B. 2012. New combinations in Neotropical Lycopodiaceae. Phytotaxa 57:10-22.

OpPenHeimer, H. L. 2003. New Hawaiian plant records for 2003. Bishop Mus. Occ. Pap. 79:8-20.

OpPENHEIMER, H. L. 2006. New Hawaii plant records for 2004. Bishop Mus. Occ. Pap. 88:10-15.

OpPenHeIMER, H. L. 2007. New plant records from Molokai, Lanai, Maui, and Hawaii for 2006. Bishop Mus. Occ. Pap. 96:17-34.

OpPeNHEIMER, H. L. 2008. New Hawaiian plant records for 2007. Bishop Mus. Occ. Pap. 100:22-38.

OpPeNHEIMER, H. L. 2010. New Hawaiian plant records for Maui County for 2008. Bishop Mus. Occ. Pap. 107:33-40.

PALMER, D. D. 2003. Hawaii's Ferns and Fern Allies. University of Hawaii Press, Honolulu.

PALMER, D. D. 2005. Pneumatopteris pendens (Thelypteridaceae), a new Hawaii endemic species of Pneumatopteris from Hawaii. Am. Fern J. 95:80-83.

PARRIS, B. S. 2007. Five new genera and three new species of Grammitidaceae (Filicales) and the reestablishment of Oreogrammitis. Gard. Bull. Singapore. 58:233-274.

[PEP] Plant Extinction Prevention. 2011. Hawaii State PEP list. http://pepphi.org [accessed June, 2012].

PRYer, K. M., A. R. SMITH, J. S. Hunt and J.-Y. Dubuisson. 2001. rbcL data reveal two monophyletic groups of filmy ferns (Filicopsida: Hymenophyllaceae), Am. J. Bot. 88:1118-1130.

RANKER, T. A. 2008. A new combination in Adenophorus (Polypodiaceae). Am. Fern J. 3:170-171.

RANKER, T. A., S. K. Floyd and P. G. Trapp. 1994. Multiple colonizations of Asplenium adiantumnigrum onto the Hawaiian archipelago. Evol. 48:1364-1370.

Ranker, T. A., J. M. O. Geiger, S. C. Kennedy, A. R. Smith, C. H. Haufler and B. S. Parris. 2003. Molecular phylogenetics and the evolution of the endemic Hawaiian genus Adenophorus (Grammitidaceae). Mol. Phylogenet. Evol. 26:337-347.

Ranker, T. A., A. R. Smith, B. S. Parris, J. M. O. Geiger, C. H. Haufler, S. C. K. Straub and H. SCHNEIDER. 2004. Phylogeny and evolution of grammitid ferns (Grammitidaceae): a case of rampant morphological homoplasy. Taxon. 53:415-428.

RavensBerg, W. J. and E. Hennipman. 1986. The Pyrrosia species formerly referred to Drymoglossum and Saxiglossum. Leiden Bot. Ser. 9:281-310. 
Robinson, W. J. 1912a. A taxonomic study of the Pteridophyta of the Hawaiian Islands. B. Torrey Bot. Club. 39:227-248.

RoBinson, W. J. 1912b. A taxonomic study of the Pteridophyta of the Hawaiian Islands-II. B. Torrey Bot. Club. 39:567-601.

Robinson, W. J. 1913. A taxonomic study of the Pteridophyta of the Hawaiian Islands-III. B. Torrey Bot. Club. 40:193-228.

Robinson, W. J. 1914. A taxonomic study of the Pteridophyta of the Hawaiian Islands-IV. B. Torrey Bot. Club. 41:51-59.

Robinson, R. C., E. SHEFField and J. M. BiRCH. 2010. Problem ferns: their impact and management. Pp. 255-322 in Mehltreter, K., L. R. Walker and J. M. Sharpe, eds. Fern Ecology. Cambridge University Press, Cambridge.

Rothfels, C. J., A. Larsson, L.-Y. Kuo, P. Korall, W.-L. Chiou and K. M. Pryer. 2012a. Overcoming deep roots, fast rates, and short internodes to resolve the ancient rapid radiation of eupolypod II ferns. Syst. Biol. 61:490-509.

RothFels, C. J., M. A. Sundue, L.-Y. Kuo, A. Larsson, M. Kato, E. Schuettpelz and K. M. Pryer. 2012b. A revised family-level classification for the eupolypod II ferns (Polypodiidae: Polypodiales). Taxon 61:515-533.

RouHAN, G., P. H. LABIAK, E. RandRIANJOHANY and F. RAKOTONDRAINIBE. 2012. Not so neotropical after all: the grammitid fern genus Leucotrichum (Polypodiaceae) is also paleotropical, as revealed by a new species from Madagascar. Syst. Bot. 37:331-338.

SAKAI, A. K., W. L. WAGNER, D. M. FERGuson and D. R. HERBST. 1995. Biogeographical and ecological correlates of dioecy in the Hawaiian flora. Ecology 76:2530-2543.

Sano, R., M. TAKamiYa, M. Ito, S. Kurita and M. HaSebe. 2000. Phylogeny of the lady fern group, tribe Physematieae (Dryopteridaceae), based on chloroplast $r b c L$ gene sequences. Mol. Phylogenet. Evol. 15:403-413.

Schneider, H., S. J. Russell, C. J. Cox, F. Bakker, S. Henderson, F. Rumsey, J. Barrett, M. GibBy and J. C. VoGEL. 2004a. Chloroplast phylogeny of Asplenioid ferns based on $r b c L$ and $t r n L-F$ spacer sequences (Polypodiidae, Aspleniaceae) and its implications for biogeography. Syst. Bot. 29:260-274.

Schneider, H. S., A. R. Smith, R. Cranfill, T. E. Hildebrand, C. H. Haufler and T. A. Ranker. 2004b. Unraveling the phylogeny of polygrammoid ferns (Polypodiaceae \& Grammitidaceae): exploring aspects of the diversification of epiphytic plants. Mol. Phylogenet. Evol. 31:1041-1063.

Schneider, H., T. A. Ranker, S. J. Russell, R. Cranflll, J. M. O. Geiger, R. Aguraiuja, K. R. Wood, M. Grundmann, K. Kloberdanz and J. C. Vogel. 2005. Origin of the endemic fern genus Diellia coincides with the renewal of Hawaiian terrestrial life in the Miocene. Proc. Roy. Soc. London, Ser. B-Biol. Sci. 272:455-460.

SChUEtTPElZ, E. and K. M. PrYer. 2007. Fern phylogeny inferred from 400 leptosporangiate species and three plastid genes. Taxon 56:1037-1050.

ShePhERD, L. D., L. R. PERRIE, B. S. PARris and P. J. BrownSEy. 2007. A molecular phylogeny for the New Zealand Blechnaceae ferns from analyses of chloroplast trnL-trnF DNA sequences. New Zeal. J. Bot. 45:67-80.

SHIVAS, M. G. 1969. A cytotaxonomic study of the Asplenium adiantum-nigrum complex. Brit. Fern Gaz. 10:68-80.

Smith, A. R., K. M. Pryer, E. Schuettpelz, P. Korall, H. Schneider and P. G. Wolf. 2006. A classification for extant ferns. Taxon 55:705-731.

Smith, A. R., K. M. Pryer, E. Schuettpelz, P. Korall, H. Schneider and P. G. Wolf. 2008. Fern Classification. Pp. 417-467 in Ranker, T. A. and C. H. Haufler, eds. Biology and Evolution of Ferns and Lycophytes. Cambridge University Press, Cambridge.

Snow, N., T. R. RANKER and D. H. LoRENCE. 2011. Taxonomic changes in Hawaiian ferns and lycophytes. Bishop Mus. Occ. Pap. 110:11-16.

St. JoHN, H 1978. The first collection of Hawaiian plants by David Nelson in 1779. Hawaiian plant studies 55. Pac. Sci. 32:315-324.

St. John, H. and Trтсомв. 1983. The vegetation of the Sandwich Islands as seen by Charles Gaudichaud in 1819: A translation with notes of Gaudichaud's "Iles Sandwich". Bishop Mus. Occ. Pap. 25:1-16. 
SundUE, M. A., M. B. IsLAm and T. A. RANKER. 2010. Systematics of grammitid ferns (Polypodiaceae): using morphology and plastid sequence data to resolve the circumscription of Melpomene and the polyphyletic genera Lellingeria and Terpsichore. Syst. Bot. 35:701-715.

TrYon, R. M. and A. F. TrYon. 1982. Ferns and Allied Plants: With Special Reference to Tropical America. Springer, New York.

[USFWS] U. S. Fish AND WiLdLIFE SERVICE. 1998. Recovery Plan for Four Species of Hawaiian Ferns. U.S. Fish and Wildlife Service, Portland, OR.

[USFWS] U. S. FiSh AND WILDLIFE SERVICE. 2004. Endangered and Threatened Wildlife and Plants; Review of Species That Are Candidates or Proposed for Listing as Endangered or Threatened; Annual Notice of Findings on Resubmitted Petitions; Annual Description of Progress on Listing Actions. Federal Register 69.

[USFWS] U. S. Fish AND WILdLIFE SERVICE. 2008. 5-Year Review Summary and Evaluation: Diellia pallida. http://ecos.fws.gov/speciesProfile/profile/speciesProfile.action?spcode=S022. [accessed April, 2011].

[USFWS] U. S. FISH AND WILDLIFE SERVICE. 2009a. Endangered and Threatened Wildlife and Plants; Initiation of 5-Year Reviews of 103 Species in Hawaii. Federal Register 74.

[USFWS] U. S. FISH AND WILDLIFE SERVICE. 2009b. 5-Year Review, short form summary: Pteris lidgatei. http://ecos.fws.gov/speciesProfile/profile/speciesProfile.action?spcode=SooW. [accessed April, 2011].

[USFWS] U. S. FISH AND WILDLIFE SERVICE. 2009c. 5-Year Review, short form summary: Diellia erecta. http://ecos.fws.gov/speciesProfile/profile/speciesProfile.action?spcode=S00P. [accessed April, 2011].

[USFWS] U. S. Fish AND WILDLIFE SERVICE. 2009d. 5-Year Review, short form summary: Ctenitis squamigera http://ecos.fws.gov/speciesProfile/profile/speciesProfile.action?spcode=S01I. [accessed April, 2011].

[USFWS] U. S. Fish AND WILDLIFE SERVICE. 2009e. 5-Year Review, short form summary: Lycopodium nutans. http://ecos.fws.gov/speciesProfile/profile/speciesProfile.action?spcode=S01L [accessed June, 2012].

[USFWS] U. S. Fish AND WILDLIFE SERVICE. 2010a. 5-Year Review, short form summary: Adenophorus periens. http://ecos.fws.gov/speciesProfile/profile/speciesProfile.action?spcode=S00M. [accessed April, 2011].

[USFWS] U. S. FiSh AND WildLIFE SERVICE. 2010b. 5-Year Review, short form summary: Diplazium molokaiense. http://ecos.fws.gov/speciesProfile/profile/speciesProfile.action?spcode=S00R. [accessed June, 2012].

[USFWS] U. S. Fish AND WILdLIFE SERvice. 2011a. 5-Year Review, short form summary: Diellia falcata. http://ecos.fws.gov/speciesProfile/profile/speciesProfile.action?spcode=S00Q [accessed June, 2012].

[USFWS] U. S. Fish AND WILDLIFE SERVICE. 2011b. 5-Year Review, short form summary: Diellia unisora http://ecos.fws.gov/speciesProfile/profile/speciesProfile.action?spcode=S01T [accessed June, 2012].

[USFWS] U. S. Fish AND WILDLIFE SERVICE. 2011c. Species profile: Doryopteris angelica. http://ecos. fws.gov/speciesProfile/profile/speciesProfile.action?spcode=S02H. [accessed April, 2011].

[USFWS] U. S. FiSH AND WILDLIFE SERVICE. 2011d. Species profile: Dryopteris crinalis var. podosorus. http://ecos.fws.gov/speciesProfile/profile/speciesProfile.action?spcode=S02I. [accessed April, 2011].

[USFWS] U. S. Fish AND WILDLIFE SERVICE. 2011e. 5-Year Review, short form summary: Huperzia mannii. http://ecos.fws.gov/speciesProfile/profile/speciesProfile.action?spcode=S01K [accessed June, 2012].

[USFWS] U. S. Fish AND WILdLIFE SERVICE. 2011f. 5-Year Review, short form summary: Marsilea villosa. http://ecos.fws.gov/speciesProfile/profile/speciesProfile.action?spcode=S00U [accessed June, 2012].

[USFWS] U. S. Fish AND WILDLIFE SERVICE. 2012a. Endangered and Threatened Wildlife and Plants; Endangered Status for 23 Species on Oahu and Designation of Critical Habitat for 124 Species. Federal Register 77(181):57647-57862. 
[USFWS] U. S. FiSH AND WILDLIFE SERVICE. 2012b. Threatened and endangered species system (TESS): summary of listed species. http://www.fws.gov/endangered/species/ [accessed September 2012].

VALIER, K. 1995. Ferns of Hawaii. University of Hawaii Press, Honolulu.

Viane, R. L. L. and T. Reichstein. 1991. Notes about Asplenium II: some new names and combinations in Asplenium L. (ASPLENIACEAE, PTERIDOPHYTA) Biol. Jaarb. 59:157-165.

WAGNER, W. H. JR. 1950. Ferns Naturalized in Hawaii. Bishop Mus. Occ. Pap. 20:95-121.

WAGNER, W. H. JR. 1981. Ferns in the Hawaiian Islands. Fiddlehead Forum 8:43-44.

WAGNER, W. H. JR. 1988. Status of the Hawaiian fern flora. Fiddlehead Forum 15:11-14.

WAGNER, W. H. JR. 1993. New species of Hawaiian pteridophytes. Contrib. Univ. Mich. Herb. 19:63-82.

WAGNER, W. H. JR. 1995. Evolution of Hawaiian ferns and fern allies in relation to their conservation status. Pac. Sci. 49:31-41.

WAgner, W. H. JR, F. S. WAgner, D. D. PAlmer and R. W. Hobdy. 1999. Taxonomic notes on the pteridophytes of Hawaii-II. Contrib. Univ. Mich. Herb. 22:135-187.

Wagner, W. L., D. R. Herbst, N. Khan and T. Flynn. 2012. Hawaiian Vascular Plant Updates: A supplement to the Manual of the Flowering Plants of Hawaii and Hawaii's Ferns and Fern Allies. Version 1.2 [3 April 2012].

WAGNER, W. L., D. R. HerbST and D. H. LORENCE. 2005-. Flora of the Hawaiian Islands website. http:// botany.si.edu/pacificislandbiodiversity/hawaiianflora/index.htm [accessed June, 2011].

Wagner, W. L., D. R. Herbst and S. H. Sohmer, (eds.) 1999. Manual of the Flowering Plants of Hawai'i. University of Hawaii Press, Honolulu.

Wang, M.-L., Z. D. Chen, X.-C. Zhang, S.-G. Lu and G.-F. Zhao. 2003. Phylogeny of the Athyriaceae: evidence from chloroplast $\operatorname{trn} L-F$ region sequences. Acta. Phytotaxon. Sin. 41:416-426.

Whitten, W. M., C. C. Jacono and N. S. Nagalingum. 2012. An Expanded Plastid Phylogeny of Marsilea with Emphasis on North American Species. Am. Fern J. 102:114-135.

Wilson, K. A. 1996. Alien ferns in Hawaii. Pac. Sci. 50:127-141.

WILSON, K. A. 2002. Continued pteridophyte invasion of Hawaii. Am. Fern J. 92:179-183.

Wilson, K. A. 2003. New records of alien pteridophytes for Hawaii. Bishop Mus. Occ. Pap. 74:5-7.

WooD, K. R. 2006. New plant records and rediscoveries within the Hawaiian Islands. Bishop Mus. Occ. Pap. 88:15-19.

WoOD, K. R. and M. LEGRANDE. 2006. An annotated checklist and new island records of flowering plants from Lehua Islet, Niihau, Hawaii. Bishop Mus. Occ. Pap. 87:19-29.

Wood, K. R. 2012. Possible Extinctions, Rediscoveries, and New Plant Records within the Hawaiian Islands. Bishop Mus. Occ. Pap. 113:91-102.

Wright, S. D., C. G. Yong, S. R. Wichman, J. W. Dawson and R. C. Gardner. 2001. Stepping stones to Hawai'i: a trans-equatorial dispersal pathway for Metrosideros (Myrtaceae) inferred from nrDNA (ITS-ETS). J. Biogeogr. 28:269-774.

Yates, L. G. 1887. Notes on Hawaiian Ferns. Geo. O. Yates, Santa Barbara.

YesilyuRT, J. C. 2005. The fern genus Doryopteris (Cheilanthoideae-Pteridaceae) in the Hawaiian Islands. Kew Bull. 60:547-558. 
APPENDIX 1. Checklist for the native and naturalized ferns and lycophytes of the Hawaiian Islands. The checklist follows the linear sequence for extant ferns and lycophytes by Christenhusz et al. (2011) with several modifications (Rothfels et al., 2012b).

${ }^{\mathrm{E}}$ endemic; ${ }^{\mathrm{I}}$ indigenous; ${ }^{\mathrm{NZ}}$ naturalized

Hawaiian Island abbreviations: $\mathrm{N}=\mathrm{Ni}$ 'ihau; $\mathrm{K}=\mathrm{Kaua} \mathrm{i} ; \mathrm{O}=\mathrm{O}$ 'ahu; $\mathrm{Mo}=$ Moloka'i; L=Lāna'i; Ma=Maui; Ka=Kaho'olawe; $\mathrm{H}=$ Hawai'i (ex)=extinct

* synonyms listed are those that represent updates subsequent to Palmer (2003)

\section{LYCOPHYTES}

1. Lycopodiaceae P. Beauv. ex Mirb.

Huperzia Bernh.

${ }^{\mathrm{E}}$ Huperzia erosa Beitel \& W. H. Wagner

Distribution: $\mathrm{K} / \mathrm{O} / \mathrm{Mo} / \mathrm{L} / \mathrm{Ma} / \mathrm{H}$

${ }^{\mathrm{I}}$ Huperzia erubescens (Brack.) Holub

Distribution: $\mathrm{K} / \mathrm{O} / \mathrm{Mo} / \mathrm{Ma} / \mathrm{H}$

${ }^{\mathrm{I}}$ Huperzia filiformis (Sw.) Holub

Distribution: $\mathrm{K} / \mathrm{O} / \mathrm{Mo} / \mathrm{L} / \mathrm{Ma} / \mathrm{H}$

${ }^{\mathrm{I}}$ Huperzia haleakalae (Brack.) Holub

Distribution: Ma (ex)

${ }^{\mathrm{E}}$ Huperzia mannii (Hillebr.) Kartesz \& Gandhi

Distribution: $\mathrm{K}(\mathrm{ex}) / \mathrm{Ma} / \mathrm{H}$

${ }^{\mathrm{E}}$ Huperzia nutans (Brack.) Rothm.

Distribution: K (ex)/O

${ }^{\mathrm{I}}$ Huperzia phyllantha (Hook. \& Arn.) Holub

Distribution: $\mathrm{K} / \mathrm{O} / \mathrm{Mo} / \mathrm{L} / \mathrm{Ma} / \mathrm{H}$

${ }^{\mathrm{I}}$ Huperzia serrata (Thunb. ex Murray) Trevis.

Distribution: $\mathrm{K} / \mathrm{O} / \mathrm{Mo} / \mathrm{L} / \mathrm{H}$

${ }^{\mathrm{E}}$ Huperzia stemmermanniae (A. C. Medeiros, W. H. Wagner \& Hobdy) Kartesz

Distribution: $\mathrm{Ma} / \mathrm{H}$

${ }^{\mathrm{E}}$ Huperzia subintegra (Hillebr.) Beitel \& W. H. Wagner

Distribution: $\mathrm{K} / \mathrm{O} / \mathrm{Mo} / \mathrm{Ma}$

Lycopodiella Holub

${ }^{\mathrm{I}}$ Lycopodiella cernua (L.) Pic. Serm.

Distribution: $\mathrm{K} / \mathrm{O} / \mathrm{Mo} / \mathrm{L} / \mathrm{Ma} / \mathrm{H}$ 


\section{Lycopodium L.}

${ }^{\mathrm{I}}$ Lycopodium venustulum Gaudich. var. venustulum Distribution: $\mathrm{K} / \mathrm{O} / \mathrm{Mo} / \mathrm{L} / \mathrm{Ma} / \mathrm{H}$

${ }^{\mathrm{E}}$ Lycopodium venustulum Gaudich. var. verticale W. H. Wagner Distribution: $\mathrm{H}$

2. Isoëtaceae Reichenb.

Isoëtes L.

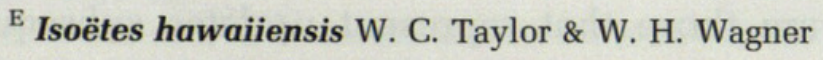

Distribution: $\mathrm{Ma} / \mathrm{H}$

3. Selaginellaceae Willk.

Selaginella P. Beauv.

${ }^{\mathrm{I}}$ Selaginella arbuscula (Kaulf.) Spring

Distribution: $\mathrm{K} / \mathrm{O} / \mathrm{Mo} / \mathrm{L} / \mathrm{Ma} / \mathrm{H}$

note: Selaginella arbuscula was previously considered an endemic species. This species has a greater distribution, occurring in the Society Islands, Ualan, Santa Cruz Island (Vanikoro), and the Marquesas Islands (Hassler and Swale, 2003).

${ }^{\text {E }}$ Selaginella deflexa Brack.

Distribution: $\mathrm{K} / \mathrm{O} / \mathrm{Mo} / \mathrm{Ma} / \mathrm{H}$

${ }^{\mathrm{NZ}}$ Selaginella kraussiana (Kunze) A. Braun

Distribution: $\mathrm{O} / \mathrm{Ma} / \mathrm{H}$

${ }^{\mathrm{NZ}}$ Selaginella stellata Spring

Distribution: $\mathrm{H}$

${ }^{\mathrm{NZ}}$ Selaginella umbrosa Lem. ex Hieron.

Distribution: $\mathrm{H}$

FERNS

1. Ophioglossaceae Martinov

Sceptridium Lyon

${ }^{\text {E }}$ Sceptridium subbifoliatum (Brack.) Lyon

Distribution: K (ex)/O (ex)/Mo (ex)/L (ex)/Ma (ex)/H (ex)

Ophioderma (Blume) Endl.

Ophioderma pendulum (L.) C. Presl

${ }^{\text {I }}$ subsp. falcatum (C. Presl) R. T. Clausen

Distribution: $\mathrm{K} / \mathrm{O} / \mathrm{Mo} / \mathrm{L} / \mathrm{Ma} / \mathrm{H}$ 
${ }^{\mathrm{I}}$ subsp. pendulum

Distribution: $\mathrm{O} / \mathrm{Mo} / \mathrm{Ma} / \mathrm{H}$

Ophioglossum L.

${ }^{I}$ Ophioglossum nudicaule L. f.

Distribution: $\mathrm{K} / \mathrm{O} / \mathrm{H}$

${ }^{\mathrm{I}}$ Ophioglossum petiolatum Hook.

Distribution: $\mathrm{K} / \mathrm{O} / \mathrm{Mo} / \mathrm{L} / \mathrm{Ma} / \mathrm{H}$

${ }^{\mathrm{I}}$ Ophioglossum polyphyllum A. Braun

Distribution: K/O/Mo/L (ex)/Ka/Ma/H

2. Psilotaceae J.W.Griff. \& Henfr.

Psilotum Sw.

${ }^{\mathrm{I}}$ Psilotum complanatum Sw.

Distribution: $\mathrm{K} / \mathrm{O} / \mathrm{Mo} / \mathrm{L} / \mathrm{Ma} / \mathrm{H}$

${ }^{\mathrm{I}}$ Psilotum nudum (L.) P. Beauv.

Distribution: N/K/O/Mo/L/Ka/Ma/H

3. Marattiaceae Kaulf.

Angiopteris Hoffm.

${ }^{\mathrm{NZ}}$ Angiopteris evecta (G. Forst.) Hoffm.

Distribution: $\mathrm{K} / \mathrm{O} / \mathrm{Mo} / \mathrm{L} / \mathrm{Ma} / \mathrm{H}$

Marattia Sw.

${ }^{\mathrm{E}}$ Marattia douglasii (C. Presl) Baker

Distribution: K/O/Mo/L/Ma/H

4. Hymenophyllaceae Mart.

Callistopteris Copel.

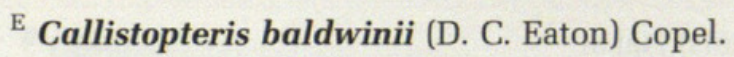

Distribution: $\mathrm{K} / \mathrm{O} / \mathrm{Mo} / \mathrm{L} / \mathrm{Ma} / \mathrm{H}$

Crepidomanes C. Presl

${ }^{\mathrm{E}}$ Crepidomanes draytonianum (Brack.) Ebihara \& K. Iwats.

Syn. Vandenboschia draytoniana (Brack.) Copel.

Distribution: $\mathrm{K} / \mathrm{O} / \mathrm{Mo} / \mathrm{L} / \mathrm{Ma} / \mathrm{H}$

${ }^{\mathrm{I}}$ Crepidomanes minutum (Blume) K. Iwats.

Syn. Gonocormus minutus (Blume) Bosch

Distribution: $\mathrm{K} / \mathrm{O} / \mathrm{Mo} / \mathrm{L} / \mathrm{Ma} / \mathrm{H}$ 


\section{${ }^{\mathrm{I}}$ Crepidomanes proliferum (Blume) Bostock}

Syn. Gonocormus prolifer (Blume) Prantl

Distribution: $\mathrm{Ma} / \mathrm{H}$

Hymenophyllum Sm.

${ }^{\mathrm{E}}$ Hymenophyllum lanceolatum Hook. \& Arn.

Syn. Sphaerocionium lanceolatum (Hook. \& Arn.) Copel.

Distribution: $\mathrm{K} / \mathrm{O} / \mathrm{Mo} / \mathrm{L} / \mathrm{Ma} / \mathrm{H}$

${ }^{\mathrm{E}}$ Hymenophyllum obtusum Hook. \& Arn.

Syn. Sphaerocionium obtusum (Hook. \& Arn.) Copel.

Distribution: $\mathrm{O} / \mathrm{Mo} / \mathrm{L} / \mathrm{Ma} / \mathrm{H}$

${ }^{\mathrm{E}}$ Hymenophyllum recurvum Gaudich.

Syn. Mecodium recurvum (Gaudich.) Copel.

Distribution: $\mathrm{K} / \mathrm{O} / \mathrm{Mo} / \mathrm{L} / \mathrm{Ma} / \mathrm{H}$

Vandenboschia Copel.

${ }^{\mathrm{E}}$ Vandenboschia cyrtotheca (Hillebr.) Copel.

Distribution: $\mathrm{K} / \mathrm{O} / \mathrm{Mo} / \mathrm{L} / \mathrm{Ma} / \mathrm{H}$

${ }^{\mathrm{E}}$ Vandenboschia davallioides (Gaudich.) Copel.

Distribution: $\mathrm{K} / \mathrm{O} / \mathrm{Mo} / \mathrm{L} / \mathrm{Ma} / \mathrm{H}$

${ }^{\mathrm{E}}$ Vandenboschia tubiflora F. S. Wagner

Distribution: $\mathrm{K}$

5. Gleicheniaceae C. Presl

Dicranopteris Bernh.

Dicranopteris linearis (Burm. f.) Underw.

Distribution: $\mathrm{K} / \mathrm{O} / \mathrm{Mo} / \mathrm{L} / \mathrm{Ma} / \mathrm{H}$

Diplopterygium (Diels) Nakai

${ }^{\mathrm{E}}$ Diplopterygium pinnatum (Kunze) Nakai

Distribution: $\mathrm{K} / \mathrm{O} / \mathrm{Mo} / \mathrm{L} / \mathrm{Ma} / \mathrm{H}$

Sticherus C. Presl

${ }^{\mathrm{E}}$ Sticherus owhyhensis (Hook.) Ching

Distribution: $\mathrm{K} / \mathrm{O} / \mathrm{Mo} / \mathrm{L} / \mathrm{Ma} / \mathrm{H}$

6. Lygodiaceae M. Roem.

Lygodium Sw.

${ }^{\mathrm{NZ}}$ Lygodium japonicum (Thunb.) Sw.

Distribution: $\mathrm{O} / \mathrm{H}$ 
7. Schizaeaceae Kaulf.

Schizaea Sm.

${ }^{\text {E }}$ Schizaea robusta Baker

Distribution: $\mathrm{K} / \mathrm{O} / \mathrm{Mo} / \mathrm{L} / \mathrm{Ma} / \mathrm{H}$

8. Marsileaceae Mirb.

Marsilea L.

${ }^{\mathrm{NZ}}$ Marsilea minuta L.

Syn. Marsilea crenata C. Presl

Distribution: $\mathrm{O}$

${ }^{\mathrm{E}}$ Marsilea villosa Kaulf.

Distribution: N/O/Mo

9. Salviniaceae Martinov

Salvinia Seg.

${ }^{\mathrm{NZ}}$ Salvinia molesta D. S. Mitch.

Distribution: $\mathrm{O} / \mathrm{H}$

Azolla Lam.

NZ Azolla filiculoides Lam.

Distribution: K/O/Mo/L/Ma/H

10. Cibotiaceae Korall

Cibotium Kaulf.

${ }^{\mathrm{E}}$ Cibotium chamissoi Kaulf.

Distribution: $\mathrm{O} / \mathrm{Mo} / \mathrm{L} / \mathrm{Ma} / \mathrm{H}$

${ }^{\mathrm{E}}$ Cibotium glaucum (Sm.) Hook. \& Arn.

Distribution: $\mathrm{K} / \mathrm{O} / \mathrm{Mo} / \mathrm{L} / \mathrm{Ma} / \mathrm{H}$

${ }^{\mathrm{E}}$ Cibotium menziesii Hook.

Distribution: $\mathrm{K} / \mathrm{O} / \mathrm{Mo} / \mathrm{L} / \mathrm{Ma} / \mathrm{H}$

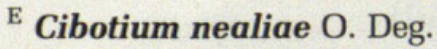

Distribution: K

11. Cyatheaceae Kaulf.

Sphaeropteris Bernh.

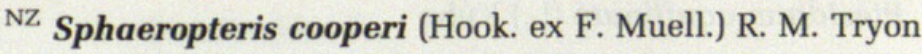
Distribution: $\mathrm{K} / \mathrm{O} / \mathrm{L} / \mathrm{Ma} / \mathrm{H}$ 
12. Dicksoniaceae M.R. Schomb.

Dicksonia L'Hér.

${ }^{N Z}$ Dicksonia fibrosa Colenso

Distribution: $\mathrm{H}$

13. Lindsaeaceae C. Presl ex M.R. Schomb.

Lindsaea Dryand. ex Sm.

${ }^{\mathrm{NZ}}$ Lindsaea ensifolia Sw.

Distribution: $\mathrm{K} / \mathrm{O} / \mathrm{Mo} / \mathrm{Ma} / \mathrm{H}$

Lindsaea repens (Bory) Thwaites

${ }^{\mathrm{E}}$ var. macraeana (Hook. \& Arn.) C. Chr.

Distribution: $\mathrm{K} / \mathrm{O} / \mathrm{Mo} / \mathrm{L} / \mathrm{Ma} / \mathrm{H}$

Sphenomeris Maxon

${ }^{\text {I }}$ Sphenomeris chinensis (L.) Maxon

Distribution: $\mathrm{K} / \mathrm{O} / \mathrm{Mo} / \mathrm{L} / \mathrm{Ma} / \mathrm{H}$

14. Dennstaedtiaceae Lotsy

Hypolepis Bernh.

Hypolepis hawaiiensis Brownsey

${ }^{\mathrm{E}}$ var. hawaiiensis

Distribution: $\mathrm{K} / \mathrm{O} / \mathrm{Mo} / \mathrm{L} / \mathrm{Ma} / \mathrm{H}$

${ }^{\mathrm{E}}$ var. mauiensis (Hillebr.) D. D. Palmer

Distribution: Ma

Microlepia C. Presl

${ }^{1}$ Microlepia speluncae (L.) T. Moore

Distribution: $\mathrm{K} / \mathrm{O} / \mathrm{Mo} / \mathrm{Ma} / \mathrm{H}$

Microlepia strigosa (Thunb.) C. Presl

${ }^{\text {E }}$ var. mauiensis (W. H. Wagner) D. D. Palmer

Distribution: $\mathrm{Ma} / \mathrm{H}$

${ }^{\mathrm{I}}$ var. strigosa

Distribution: $\mathrm{K} / \mathrm{O} / \mathrm{Mo} / \mathrm{L} / \mathrm{Ma} / \mathrm{H}$

Pteridium Gled. ex Scop.

Pteridium aquilinum (L.) Kuhn

${ }^{\text {E }}$ subsp. decompositum (Gaudich.) Lamoureux ex J. A. Thomson

Distribution: $\mathrm{K} / \mathrm{O} / \mathrm{Mo} / \mathrm{L} / \mathrm{Ma} / \mathrm{H}$ 
15. Pteridaceae E. D. M. Kirchn.

Adiantum L.

NZ Adiantum 'Edwinii'

Distribution: O/L/Ma

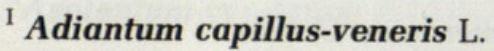

Distribution: N/K/O/Mo/L/Ma/H

${ }^{N Z}$ Adiantum hispidulum Sw.

Distribution: $\mathrm{K} / \mathrm{O} / \mathrm{Mo} / \mathrm{L} / \mathrm{Ka} / \mathrm{Ma} / \mathrm{H}$

${ }^{\mathrm{NZ}}$ Adiantum raddianum C. Presl

Distribution: $\mathrm{K} / \mathrm{O} / \mathrm{Mo} / \mathrm{L} / \mathrm{Ma} / \mathrm{H}$

${ }^{\mathrm{NZ}}$ Adiantum tenerum Sw.

Distribution: O/Mo/Ma

Ceratopteris Brongn.

${ }^{\mathrm{NZ}}$ Ceratopteris gaudichaudii Brongn.

var. vulgaris Masuyama \& Watano

Distribution: $\mathrm{K} / \mathrm{O} / \mathrm{H}$

Cheilanthes Sw.

${ }^{\mathrm{NZ}}$ Cheilanthes viridis (Forssk.) Sw.

Distribution: $\mathrm{K} / \mathrm{O} / \mathrm{L} / \mathrm{Ma} / \mathrm{H}$

Coniogramme Fée

${ }^{\mathrm{E}}$ Coniogramme pilosa (Brack.) Hieron.

Distribution: $\mathrm{K} / \mathrm{O} / \mathrm{Mo} / \mathrm{L} / \mathrm{Ma} / \mathrm{H}$

Doryopteris J. Sm.

${ }^{\mathrm{E}}$ Doryopteris angelica K. R. Wood \& W. H. Wagner

Distribution: K

${ }^{\mathrm{E}}$ Doryopteris decipiens (Hook.) J. Sm.

Distribution: N/K/O/Mo/L/Ka/Ma/H

${ }^{\mathrm{E}}$ Doryopteris decora Brack.

Distribution: $\mathrm{K} / \mathrm{O} / \mathrm{Mo} / \mathrm{L} / \mathrm{Ka} / \mathrm{Ma} / \mathrm{H}$

${ }^{\text {E }}$ Doryopteris takeuchii (W. H. Wagner) W. H. Wagner

Distribution: O

Haplopteris C. Presl

${ }^{\mathrm{I}}$ Haplopteris elongata (Sw.) E. H. Crane

Distribution: $\mathrm{K} / \mathrm{O} / \mathrm{Mo} / \mathrm{L} / \mathrm{Ma} / \mathrm{H}$ 
Pellaea Link

${ }^{\mathrm{I}}$ Pellaea ternifolia (Cav.) Link

Distribution: $\mathrm{K} / \mathrm{O} / \mathrm{Mo} / \mathrm{L} / \mathrm{Ma} / \mathrm{H}$

Pityrogramma Link

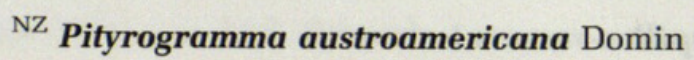

Distribution: N/K/O/Mo/L/Ka/Ma/H

${ }^{N Z}$ Pityrogramma calomelanos (L.) Link

Distribution: N/K/O/Mo/L/Ka/Ma/H

Pteris L.

${ }^{\mathrm{I}}$ Pteris cretica L.

Distribution: $\mathrm{K} / \mathrm{O} / \mathrm{Mo} / \mathrm{L} / \mathrm{Ma} / \mathrm{H}$

${ }^{\mathrm{I}}$ Pteris excelsa Gaudich.

Distribution: K/O/Mo/L/Ma/H

${ }^{\mathrm{E}}$ Pteris hillebrandii Copel.

Distribution: $\mathrm{K} / \mathrm{O} / \mathrm{Mo} / \mathrm{L} / \mathrm{Ma} / \mathrm{H}$

${ }^{\mathrm{E}}$ Pteris irregularis Kaulf.

Distribution: $\mathrm{K} / \mathrm{O} / \mathrm{Mo} / \mathrm{L} / \mathrm{Ma} / \mathrm{H}$

${ }^{\mathrm{E}}$ Pteris lidgatei (Hillebr.) Christ

Distribution: $\mathrm{O} / \mathrm{Mo} / \mathrm{Ma}$

${ }^{\mathrm{NZ}}$ Pteris tremula R. Br.

Distribution: $\mathrm{Ma}$

${ }^{N Z}$ Pteris vittata L.

Distribution: $\mathrm{K} / \mathrm{O} / \mathrm{Mo} / \mathrm{L} / \mathrm{Ma} / \mathrm{H}$

16. Cystopteridaceae (Payer) Shmakov

Cystopteris Bernh.

${ }^{\mathrm{E}}$ Cystopteris douglasii Hook.

Distribution: $\mathrm{Ma} / \mathrm{H}$

${ }^{\mathrm{E}}$ Cystopteris sandwicensis Brack.

Distribution: $\mathrm{K} / \mathrm{O} / \mathrm{L} / \mathrm{Ma}$

17. Aspleniaceae Newman

Asplenium L.

${ }^{\text {E }}$ Asplenium acuminatum Hook. \& Arn.

Distribution: $\mathrm{K} / \mathrm{O} / \mathrm{Mo} / \mathrm{L} / \mathrm{Ma} / \mathrm{H}$ 
${ }^{\mathrm{I}}$ Asplenium adiantum-nigrum L.

Distribution: K/O/Mo/L/Ma/H

${ }^{\mathrm{I}}$ Asplenium aethiopicum (Burm. f.) Bech.

Distribution: K/O/Mo/L/Ma/H

${ }^{\mathrm{I}}$ Asplenium caudatum G.Forst.

Syn. Asplenium horridum Kaulf. var. glabratum (W. J. Rob.) D. D. Palmer; Asplenium horridum Kaulf. var. horridum

Distribution: K/O/Mo/L/Ma/H

Asplenium contiguum Kaulf.

${ }^{\mathrm{E}}$ var. contiguum

Distribution: $\mathrm{K} / \mathrm{O} / \mathrm{Mo} / \mathrm{L} / \mathrm{Ma} / \mathrm{H}$

${ }^{\mathrm{E}}$ var. hirtulum C. Chr.

Distribution: $\mathrm{K} / \mathrm{Ma}$

${ }^{\mathrm{E}}$ Asplenium dielerectum Viane

Syn. Diellia erecta Brack.

Distribution: O/Mo/L (ex)/Ma/H

${ }^{\mathrm{E}}$ Asplenium dielfalcatum Viane

Syn. Diellia falcata Brack.

Distribution: $\mathrm{O}$

${ }^{\mathrm{E}}$ Asplenium diellaciniatum Viane

Distribution: K

${ }^{\mathrm{E}}$ Asplenium dielmannii Viane

Syn. Diellia mannii (D. C. Eaton) W. J. Rob.

Distribution: K

${ }^{\mathrm{E}}$ Asplenium dielpallidum N. Snow

Syn. Diellia pallida W. H. Wagner

Distribution: $\mathrm{K}$

${ }^{\mathrm{I}}$ Asplenium excisum C. Presl

Distribution: $\mathrm{K} / \mathrm{O} / \mathrm{Mo} / \mathrm{L} / \mathrm{Ma} / \mathrm{H}$

${ }^{\mathrm{E}}$ Asplenium haleakalense W. H. Wagner

Distribution: $\mathrm{Ma} / \mathrm{H}$

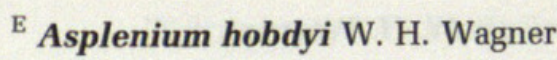

Distribution: $\mathrm{K} / \mathrm{Mo} / \mathrm{Ma} / \mathrm{H}$

${ }^{\mathrm{I}}$ Asplenium insiticium Brack.

Distribution: $\mathrm{K} / \mathrm{O} / \mathrm{Mo} / \mathrm{L} / \mathrm{Ma} / \mathrm{H}$ 
${ }^{\mathrm{E}}$ Asplenium kaulfussii Schltdl.

Distribution: $\mathrm{K} / \mathrm{O} / \mathrm{Mo} / \mathrm{L} / \mathrm{Ma} / \mathrm{H}$

${ }^{\mathrm{E}}$ Asplenium leucostegioides Baker

Syn. Diellia leucostegioides (Baker) W. H. Wagner

Distribution: Ma (ex)

${ }^{\mathrm{I}}$ Asplenium lobulatum Mett.

Distribution: $\mathrm{K} / \mathrm{O} / \mathrm{Mo} / \mathrm{L} / \mathrm{Ma} / \mathrm{H}$

${ }^{\mathrm{E}}$ Asplenium macraei Hook. \& Grev.

Distribution: $\mathrm{K} / \mathrm{O} / \mathrm{Mo} / \mathrm{L} / \mathrm{Ma} / \mathrm{H}$

${ }^{\mathrm{I}}$ Asplenium monanthes $\mathrm{L}$.

Distribution: $\mathrm{Ma} / \mathrm{H}$

Asplenium nidus $\mathrm{L}$.

Distribution: $\mathrm{K} / \mathrm{O} / \mathrm{Mo} / \mathrm{L} / \mathrm{Ma} / \mathrm{H}$

${ }^{\mathrm{I}}$ Asplenium normale D. Don

Distribution: $\mathrm{K} / \mathrm{O} / \mathrm{Mo} / \mathrm{L} / \mathrm{Ma} / \mathrm{H}$

Asplenium peruvianum Desv.

${ }^{\mathrm{E}}$ var. insulare (C. V. Morton) D. D. Palmer

Distribution: $\mathrm{Ma} / \mathrm{H}$

${ }^{\mathrm{I}}$ Asplenium polyodon G. Forst.

Distribution: $\mathrm{K} / \mathrm{O} / \mathrm{Mo} / \mathrm{L} / \mathrm{Ma} / \mathrm{H}$

${ }^{\mathrm{E}}$ Asplenium schizophyllum C. Chr.

Distribution: $\mathrm{K} / \mathrm{H}$

${ }^{\mathrm{E}}$ Asplenium sphenotomum Hillebr.

Distribution: $\mathrm{K} / \mathrm{O} / \mathrm{Mo} / \mathrm{L} / \mathrm{Ma} / \mathrm{H}$

Asplenium trichomanes L.

${ }^{\mathrm{E}}$ subsp. densum (Brack.) W. H. Wagner

Distribution: $\mathrm{Ma} / \mathrm{H}$

${ }^{\mathrm{I}}$ Asplenium unilaterale Lam.

Distribution: $\mathrm{K} / \mathrm{O} / \mathrm{Mo} / \mathrm{L} / \mathrm{Ma} / \mathrm{H}$

${ }^{\mathrm{E}}$ Asplenium unisorum (W. H. Wagner) Viane

Syn. Diellia unisora W. H. Wagner

Distribution: $\mathrm{O}$ 
18. Thelypteridaceae Ching ex Pic. Serm.

Cyclosorus Link

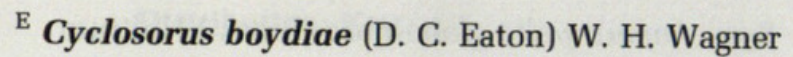
Syn. Christella boydiae (D.C. Eaton) Holttum

Distribution: O/Ma

${ }^{\mathrm{E}}$ Cyclosorus cyatheoides (Kaulf.) Farw.

Syn. Christella cyatheoides (Kaulf.) Holttum

Distribution: $\mathrm{K} / \mathrm{O} / \mathrm{Mo} / \mathrm{L} / \mathrm{Ma} / \mathrm{H}$

${ }^{\mathrm{NZ}}$ Cyclosorus dentatus (Forssk.) Ching

Syn. Christella dentata (Forssk.) Brownsey \& Jermy

Distribution: $\mathrm{K} / \mathrm{O} / \mathrm{Mo} / \mathrm{L} / \mathrm{Ma} / \mathrm{H}$

${ }^{\mathrm{E}}$ Cyclosorus hudsonianus (Brack.) Ching

Syn. Pneumatopteris hudsoniana (Brack.) Holttum

Distribution: $\mathrm{K} / \mathrm{O} / \mathrm{Mo} / \mathrm{L} / \mathrm{Ma} / \mathrm{H}$

${ }^{\mathrm{I} C y c l o s o r u s ~ i n t e r r u p t u s ~(W i l l d .) ~ H . ~ I t o ̂ ~}$

Distribution: $\mathrm{K} / \mathrm{O} / \mathrm{Mo} / \mathrm{L} / \mathrm{Ma} / \mathrm{H}$

${ }^{N Z}$ Cyclosorus parasiticus (L.) Farw.

Syn. Christella parasitica (L.) H. Lév.

Distribution: $\mathrm{K} / \mathrm{O} / \mathrm{Mo} / \mathrm{L} / \mathrm{Ma} / \mathrm{H}$

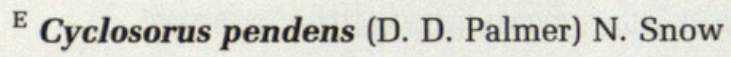

Syn. Pneumatopteris pendens D. D. Palmer

Distribution: $\mathrm{K} / \mathrm{O} / \mathrm{Mo} / \mathrm{Ma} / \mathrm{H}$

${ }^{\mathrm{E}}$ Cyclosorus sandwicensis (Brack.) Copel.

Syn. Pneumatopteris sandwicensis (Brack.) Holttum

Distribution: $\mathrm{K} / \mathrm{O} / \mathrm{Mo} / \mathrm{L} / \mathrm{Ma} / \mathrm{H}$

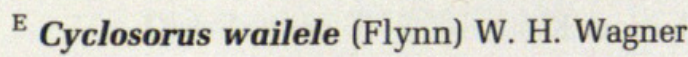

Syn. Christella wailele (Flynn) D. D. Palmer

Distribution: $\mathrm{K}$

Macrothelypteris (H. Itô) Ching

${ }^{\mathrm{NZ}}$ Macrothelypteris torresiana (Gaudich.) Ching

Distribution: $\mathrm{K} / \mathrm{O} / \mathrm{Ma} / \mathrm{H}$

Pseudophegopteris Ching

${ }^{\text {E }}$ Pseudophegopteris keraudreniana (Gaudich.) Holttum

Distribution: $\mathrm{K} / \mathrm{O} / \mathrm{Mo} / \mathrm{L} / \mathrm{Ma} / \mathrm{H}$ 
Thelypteris Schmidel

${ }^{\text {E }}$ Thelypteris globulifera (Brack.) C. F. Reed

Syn. Amauropelta globulifera (Brack.) Holttum

Distribution: $\mathrm{K} / \mathrm{O} / \mathrm{Mo} / \mathrm{L} / \mathrm{Ma} / \mathrm{H}$

19. Blechnaceae Newman

Blechnum L.

${ }^{\mathrm{NZ}}$ Blechnum appendiculatum Willd.

Distribution: $\mathrm{K} / \mathrm{O} / \mathrm{Mo} / \mathrm{L} / \mathrm{Ma} / \mathrm{H}$

${ }^{\mathrm{NZ}}$ Blechnum orientale L.

Distribution: O

Doodia R. Br.

${ }^{\mathrm{E}}$ Doodia kunthiana Gaudich.

Distribution: $\mathrm{K} / \mathrm{O} / \mathrm{Mo} / \mathrm{L} / \mathrm{Ma} / \mathrm{H}$

${ }^{\mathrm{E}}$ Doodia lyonii O. Deg.

Distribution: $\mathrm{K} / \mathrm{O} / \mathrm{Ma} / \mathrm{H}$ (ex)

Sadleria Kaulf.

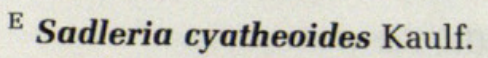

Distribution: $\mathrm{K} / \mathrm{O} / \mathrm{Mo} / \mathrm{L} / \mathrm{Ma} / \mathrm{H}$

${ }^{\mathrm{E}}$ Sadleria pallida Hook. \& Arn.

Distribution: $\mathrm{K} / \mathrm{O} / \mathrm{Mo} / \mathrm{L} / \mathrm{Ma} / \mathrm{H}$

${ }^{\text {E }}$ Sadleria souleyetiana (Gaudich.) T. Moore

Distribution: $\mathrm{K} / \mathrm{O} / \mathrm{Mo} / \mathrm{L} / \mathrm{Ma} / \mathrm{H}$

${ }^{\text {E }}$ Sadleria squarrosa (Gaudich.) T. Moore

Distribution: $\mathrm{K} / \mathrm{O} / \mathrm{Mo} / \mathrm{L} / \mathrm{Ma} / \mathrm{H}$

${ }^{\text {E }}$ Sadleria unisora (Baker) W. J. Rob.

Distribution: K

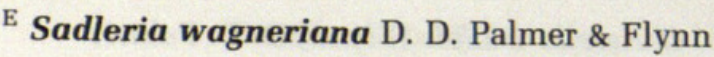

Distribution: $\mathrm{K}$

20. Athyriaceae Alston

Athyrium Roth

${ }^{\mathrm{E}}$ Athyrium microphyllum (Sm.) Alston

Distribution: $\mathrm{K} / \mathrm{O} / \mathrm{Mo} / \mathrm{L} / \mathrm{Ma} / \mathrm{H}$ 
Deparia Hook. \& Grev.

${ }^{\mathrm{E}}$ Deparia cataracticola M. Kato

Distribution: $\mathrm{K}$

${ }^{\mathrm{E}}$ Deparia fenzliana (Luerss.) M. Kato

Distribution: $\mathrm{K} / \mathrm{O} / \mathrm{Mo} / \mathrm{L} / \mathrm{Ma} / \mathrm{H}$

${ }^{\mathrm{E}}$ Deparia kaalaana (Copel.) M. Kato

Distribution: $\mathrm{K}(\mathrm{ex}) / \mathrm{Ma}(\mathrm{ex}) / \mathrm{H}(\mathrm{ex})$

${ }^{\mathrm{E}}$ Deparia marginalis (Hillebr.) M. Kato

Distribution: $\mathrm{K} / \mathrm{Mo} / \mathrm{L} / \mathrm{Ma} / \mathrm{H}$

${ }^{\mathrm{NZ}}$ Deparia petersenii (Kunze) M. Kato

Distribution: $\mathrm{K} / \mathrm{O} / \mathrm{Mo} / \mathrm{L} / \mathrm{Ma} / \mathrm{H}$

${ }^{\mathrm{E}}$ Deparia prolifera (Kaulf.) Hook. \& Grev.

Distribution: $\mathrm{K} / \mathrm{O} / \mathrm{Mo} / \mathrm{L} / \mathrm{Ma} / \mathrm{H}$

Diplazium Sw.

${ }^{\mathrm{E}}$ Diplazium arnottii Brack.

Distribution: $\mathrm{K} / \mathrm{O} / \mathrm{Mo} / \mathrm{L} / \mathrm{Ma} / \mathrm{H}$

${ }^{\mathrm{NZ}}$ Diplazium esculentum (Retz.) Sw.

Distribution: $\mathrm{K} / \mathrm{O} / \mathrm{Mo} / \mathrm{L} / \mathrm{Ma} / \mathrm{H}$

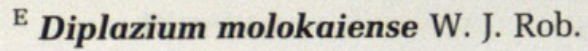

Distribution: K (ex)/O (ex)/Mo (ex)/L (ex)/Ma

${ }^{\mathrm{E}}$ Diplazium sandwichianum (C. Presl) Diels

Distribution: $\mathrm{K} / \mathrm{O} / \mathrm{Mo} / \mathrm{L} / \mathrm{Ma} / \mathrm{H}$

21. Dryopteridaceae Herter

Arachniodes Blume

${ }^{\text {E }}$ Arachniodes insularis W. H. Wagner

Distribution: $\mathrm{K} / \mathrm{O} / \mathrm{Mo} / \mathrm{Ma} / \mathrm{H}$

Ctenitis (C. Chr.) C. Chr.

${ }^{\mathrm{E}}$ Ctenitis latifrons (Brack.) Copel.

Distribution: $\mathrm{K} / \mathrm{O} / \mathrm{Mo} / \mathrm{L} / \mathrm{Ma} / \mathrm{H}$

${ }^{\text {E }}$ Ctenitis squamigera (Hook. \& Arn.) Copel.

Distribution: K/O/Mo/L/Ma

Cyrtomium C. Presl

${ }^{\text {I }}$ Cyrtomium caryotideum (Wall. ex Hook. \& Grev.) C. Presl Distribution: K/O/Mo/L/Ma/H 
${ }^{\mathrm{NZ}}$ Cyrtomium falcatum (L. f.) C. Presl

Distribution: $\mathrm{K} / \mathrm{O} / \mathrm{Mo} / \mathrm{L} / \mathrm{Ma} / \mathrm{H}$

Dryopteris Adans.

Dryopteris crinalis (Hook. \& Arn.) C. Chr.

${ }^{\mathrm{E}}$ var. crinalis

Distribution: $\mathrm{K} / \mathrm{O} / \mathrm{Mo} / \mathrm{L} / \mathrm{Ma} / \mathrm{H}$

${ }^{\text {E }}$ var. podosora (W. H. Wagner) D. D. Palmer

Distribution: K

Dryopteris fuscoatra (Hillebr.) W. J. Rob.

${ }^{\mathrm{E}}$ var. fuscoatra

Distribution: $\mathrm{K} / \mathrm{O} / \mathrm{Mo} / \mathrm{L} / \mathrm{Ma} / \mathrm{H}$

${ }^{\mathrm{E}}$ var. lamoureuxii Fraser-Jenk.

Distribution: Ma

Dryopteris glabra (Brack.) Kuntze

${ }^{\mathrm{E}}$ var. alboviridis (W. H. Wagner) D. D. Palmer

Distribution: $\mathrm{K}$

${ }^{\mathrm{E}}$ var. flynnii D. D. Palmer

Distribution: K

${ }^{\mathrm{E}}$ var. glabra

Distribution: $\mathrm{K} / \mathrm{O} / \mathrm{Mo} / \mathrm{L} / \mathrm{Ma} / \mathrm{H}$

${ }^{\text {E }}$ var. hobdyana (W. H. Wagner) D. D. Palmer

Distribution: Ma

${ }^{\mathrm{E}}$ var. nuda (Underw.) Fraser-Jenk.

Distribution: K/O/Mo/Ma

${ }^{\mathrm{E}}$ var. pusilla (Hillebr.) Fraser-Jenk.

Distribution: $\mathrm{K}$

${ }^{\mathrm{E}}$ var. soripes (Hillebr.) Herat ex Fraser-Jenk.

Distribution: $\mathrm{K} / \mathrm{O} / \mathrm{Mo} / \mathrm{Ma} / \mathrm{H}$

${ }^{\mathrm{E}}$ Dryopteris hawaiiensis (Hillebr.) W. J. Rob.

Distribution: $\mathrm{K} / \mathrm{O} / \mathrm{Mo} / \mathrm{Ma} / \mathrm{H}$

${ }^{\mathrm{E}}$ Dryopteris mauiensis $\mathrm{C}$. Chr.

Distribution: $\mathrm{K} / \mathrm{O} / \mathrm{Mo} / \mathrm{L} / \mathrm{Ma} / \mathrm{H}$ 
${ }^{\mathrm{E}}$ Dryopteris rubiginosa (Brack.) Kuntze

Syn. Nothoperanema rubiginosum (Brack.) A.R. Sm. \& D. D. Palmer

Distribution: $\mathrm{K} / \mathrm{O} / \mathrm{Mo} / \mathrm{L} / \mathrm{Ma} / \mathrm{H}$

${ }^{\mathrm{E}}$ Dryopteris sandwicensis (Hook. \& Arn.) C. Chr.

Distribution: $\mathrm{K} / \mathrm{O} / \mathrm{Mo} / \mathrm{L} / \mathrm{Ma} / \mathrm{H}$

${ }^{\text {E }}$ Dryopteris subbipinnata W. H. Wagner \& Hobdy

Distribution: $\mathrm{Ma} / \mathrm{H}$

${ }^{\mathrm{E}}$ Dryopteris tetrapinnata W. H. Wagner \& Hobdy

Distribution: Ma

Dryopteris unidentata (Hook. \& Arn.) C. Chr.

${ }^{\mathrm{E}}$ var. paleacea (Hillebr.) Herat ex Fraser-Jenk.

Distribution: $\mathrm{K} / \mathrm{O} / \mathrm{Mo} / \mathrm{Ma} / \mathrm{H}$

${ }^{\mathrm{E}}$ var. unidentata

Distribution: $\mathrm{K} / \mathrm{O} / \mathrm{Mo} / \mathrm{L} / \mathrm{Ma} / \mathrm{H}$

${ }^{\mathrm{I}}$ Dryopteris wallichiana (Spreng.) Hyl.

Distribution: $\mathrm{K} / \mathrm{O} / \mathrm{Mo} / \mathrm{Ma} / \mathrm{H}$

Elaphoglossum Schott ex J. Sm.

${ }^{\mathrm{E}}$ Elaphoglossum aemulum (Kaulf.) Brack.

Distribution: $\mathrm{K} / \mathrm{O} / \mathrm{Mo} / \mathrm{L} / \mathrm{Ma} / \mathrm{H}(\mathrm{ex})$

${ }^{\mathrm{E}}$ Elaphoglossum alatum Gaudich.

Distribution: $\mathrm{O}$

${ }^{\mathrm{E}}$ Elaphoglossum crassicaule Copel.

Distribution: $\mathrm{K}$

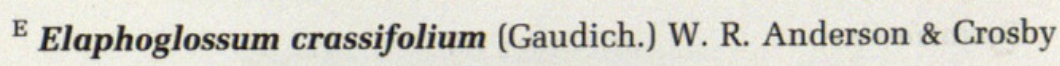

Distribution: $\mathrm{K} / \mathrm{O} / \mathrm{Mo} / \mathrm{L} / \mathrm{Ma} / \mathrm{H}$

${ }^{\mathrm{E}}$ Elaphoglossum fauriei Copel.

Distribution: $\mathrm{O} / \mathrm{Mo}$

${ }^{\mathrm{I}}$ Elaphoglossum paleaceum (Hook. \& Grev.) Sledge

Distribution: $\mathrm{K} / \mathrm{O} / \mathrm{Mo} / \mathrm{L} / \mathrm{Ma} / \mathrm{H}$

${ }^{\mathrm{E}}$ Elaphoglossum parvisquameum Skottsb.

Distribution: $\mathrm{Mo} / \mathrm{L} / \mathrm{Ma} / \mathrm{H}$

${ }^{\mathrm{E}}$ Elaphoglossum pellucidum Gaudich.

Distribution: $\mathrm{K} / \mathrm{O} / \mathrm{Mo} / \mathrm{Ma} / \mathrm{H}$ 


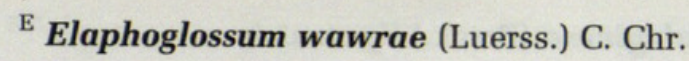

Distribution: $\mathrm{K} / \mathrm{O} / \mathrm{Mo} / \mathrm{Ma} / \mathrm{H}$

\section{Polystichum Roth}

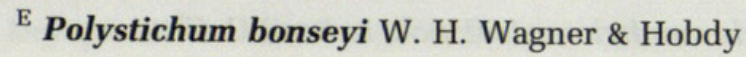

Distribution: $\mathrm{Ma} / \mathrm{H}$

${ }^{\mathrm{E}}$ Polystichum haleakalense Brack.

Distribution: $\mathrm{Ma} / \mathrm{H}$

${ }^{\mathrm{E}}$ Polystichum hillebrandii Carruth.

Distribution: $\mathrm{Ma} / \mathrm{H}$

22. Nephrolepidaceae Pic. Serm.

Nephrolepis Schott

${ }^{\text {NZ }}$ Nephrolepis brownii (Desv.) Hovenkamp \& Miyam.

Syn. Nephrolepis multiflora (Roxb.) F. M. Jarrett ex C. V. Morton

Distribution: N/K/O/Mo/L/Ka/Ma/H

${ }^{\mathrm{I}}$ Nephrolepis cordifolia (L.) C. Presl

Distribution: $\mathrm{K} / \mathrm{O} / \mathrm{Mo} / \mathrm{L} / \mathrm{Ma} / \mathrm{H}$

${ }^{\mathrm{E}}$ Nephrolepis exaltata (L.) Schott subsp. hawaiiensis W. H. Wagner Distribution: N/K/O/Mo/L/Ma/H

${ }^{N Z}$ Nephrolepis falcata (Cav.) C. Chr. 'Furcans'

Distribution: $\mathrm{K} / \mathrm{O} / \mathrm{Mo} / \mathrm{L} / \mathrm{Ma} / \mathrm{H}$

${ }^{\mathrm{NZ}}$ Nephrolepis hirsutula (G. Forst.) C. Presl 'Superba'

Distribution: $\mathrm{K} / \mathrm{Ma}$

23. Tectariaceae Panigrahi

Tectaria Cav.

${ }^{\mathrm{E}}$ Tectaria gaudichaudii (Mett.) Maxon

Distribution: $\mathrm{K} / \mathrm{O} / \mathrm{Mo} / \mathrm{L} / \mathrm{Ma} / \mathrm{H}$

${ }^{N Z}$ Tectaria incisa Cav.

Distribution: $\mathrm{K} / \mathrm{O} / \mathrm{Ma} / \mathrm{H}$

24. Davalliaceae M. R. Schomb. ex A. B. Frank

Davallia Sm.

${ }^{\mathrm{NZ}}$ Davallia fejeensis Hook.

Distribution: $\mathrm{O} / \mathrm{Ma}$ 
25. Polypodiaceae Bercht. \& J. Presl

Adenophorus Gaudich.

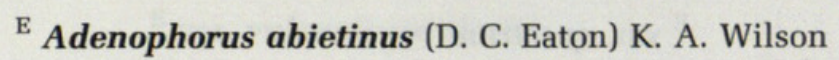
Distribution: K/O/L/Ma

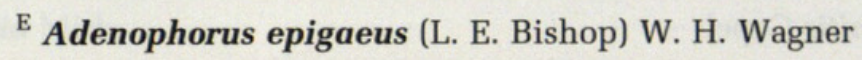
Distribution: $\mathrm{K}$

${ }^{\mathrm{E}}$ Adenophorus haalilioanus (Brack.) K. A. Wilson Distribution: $\mathrm{K} / \mathrm{O}$

E Adenophorus hymenophylloides (Kaulf.) Hook. \& Grev. Distribution: $\mathrm{K} / \mathrm{O} / \mathrm{Mo} / \mathrm{L} / \mathrm{Ma} / \mathrm{H}$

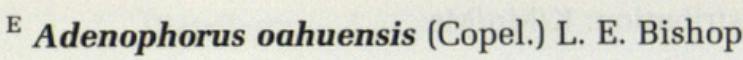
Distribution: $\mathrm{O}$

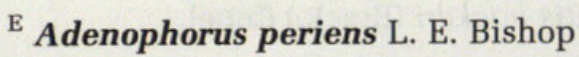
Distribution: K/O (ex)/Mo/L (ex)/Ma (ex)/H

Adenophorus pinnatifidus Gaudich.

${ }^{\mathrm{E}}$ var. pinnatifidus

Distribution: $\mathrm{K} / \mathrm{O} / \mathrm{Mo} / \mathrm{L} / \mathrm{Ma} / \mathrm{H}$

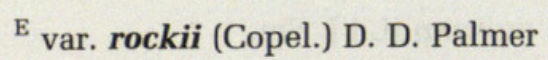

Distribution: $\mathrm{K} / \mathrm{O} / \mathrm{Mo} / \mathrm{Ma}$

Adenophorus tamariscinus (Kaulf.) Hook. \& Grev.

${ }^{\mathrm{E}}$ var. montanus (Hillebr.) L. E. Bishop

Distribution: $\mathrm{Mo} / \mathrm{Ma} / \mathrm{H}$

${ }^{\mathrm{E}}$ var. tamariscinus

Distribution: K/O/Mo/L/Ma/H

${ }^{\mathrm{E}}$ Adenophorus tenellus (Kaulf.) Ranker

Syn. Grammitis tenella Kaulf.

Distribution: K/O/Mo/L/Ma/H

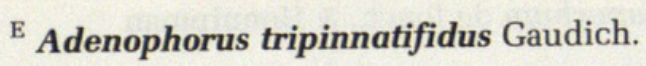

Distribution: $\mathrm{K} / \mathrm{O} / \mathrm{Mo} / \mathrm{L} / \mathrm{Ma} / \mathrm{H}$

Lepisorus (J. Sm.) Ching

${ }^{I}$ Lepisorus thunbergianus (Kaulf.) Ching

Distribution: $\mathrm{K} / \mathrm{O} / \mathrm{Mo} / \mathrm{L} / \mathrm{Ma} / \mathrm{H}$

Microsorum Link

Microsorum spectrum (Kaulf.) Copel. 


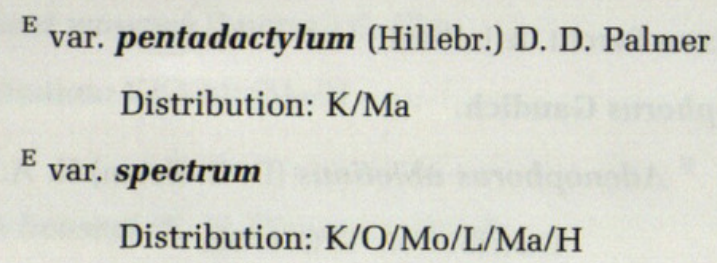

Oreogrammitis Copel.

${ }^{\mathrm{E}}$ Oreogrammitis baldwinii (Baker) Parris

Syn. Grammitis baldwinii (Baker) Copel.

Distribution: K

${ }^{\text {E }}$ Oreogrammitis forbesiana (W. H. Wagner) Parris

Syn. Grammitis forbesiana W. H. Wagner

Distribution: $\mathrm{K} / \mathrm{Mo} / \mathrm{Ma}$

${ }^{\mathrm{E}}$ Oreogrammitis hookeri (Brack.) Parris

Syn. Grammitis hookeri (Brack.) Copel.

Distribution: $\mathrm{K} / \mathrm{O} / \mathrm{Mo} / \mathrm{L} / \mathrm{Ma} / \mathrm{H}$

note: Oreogrammitis hookeri was previously thought to be an indigenous species, but is now considered as distinct from species found in Fiji and American Samoa (B. Parris, pers. comm.)

Phlebodium (R. Br.) J. Sm.

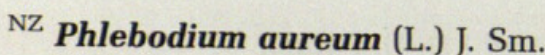

Distribution: $\mathrm{K} / \mathrm{O} / \mathrm{Mo} / \mathrm{L} / \mathrm{Ma} / \mathrm{H}$

Phymatosorus Pic. Serm.

${ }^{N Z}$ Phymatosorus grossus (Langsd. \& Fisch.) Brownlie

Distribution: $\mathrm{K} / \mathrm{O} / \mathrm{Mo} / \mathrm{L} / \mathrm{Ma} / \mathrm{H}$

${ }^{\text {NZ }}$ Phymatosorus scolopendria (Burm. f.) Pic. Serm.

Distribution: Ma

Platycerium Desv.

${ }^{\mathrm{NZ}}$ Platycerium bifurcatum (Cav.) C. Chr.

Distribution: $\mathrm{O} / \mathrm{Ma} / \mathrm{H}$

${ }^{\mathrm{NZ}}$ Platycerium superbum de Jonch. \& Hennipman

Distribution: O

Polypodium L.

Polypodium pellucidum Kaulf.

${ }^{\text {E }}$ var. acuminatum D. D. Palmer

Distribution: K/Ma 
${ }^{\mathrm{E}}$ var. pellucidum

Distribution: $\mathrm{K} / \mathrm{O} / \mathrm{Mo} / \mathrm{L} / \mathrm{Ma} / \mathrm{H}$

${ }^{\mathrm{E}}$ var. vulcanicum Skottsb.

Distribution: $\mathrm{Mo} / \mathrm{Ma} / \mathrm{H}$

Pyrrosia Mirb.

${ }^{\text {NZ }}$ Pyrrosia piloselloides (L.) M. G. Price

Distribution: O

Stenogrammitis Labiak

${ }^{\text {E }}$ Stenogrammitis saffordii (Maxon) Labiak

Syn. Lellingeria saffordii (Maxon) A. R. Sm. \& R. C. Moran

Distribution: $\mathrm{K} / \mathrm{O} / \mathrm{Mo} / \mathrm{L} / \mathrm{Ma} / \mathrm{H}$ 
APPENDIX 2. Estimated origins of 78 Hawaiian fern and lycophyte taxa based on molecular phylogenetic studies and/or geographical distributions.

${ }^{\mathrm{E}}$ endemic; ${ }^{\mathrm{I}}$ indigenous

${ }^{*}=$ origin inferred based on distribution of genus or species

\begin{tabular}{|c|c|c|c|}
\hline Status & Taxa & $\begin{array}{c}\text { Distribution of } \\
\text { lineage sister to } \\
\text { Hawaiian Lineage }\end{array}$ & References \\
\hline & Ferns & & \\
\hline $\mathrm{E}$ & Adenophorus - 10 species & Neotropics & Ranker et al., 2004 \\
\hline $\mathrm{E}$ & Arachniodes insularis & Asia & * \\
\hline $\mathrm{E}$ & Asplenium acuminatum & unknown & \\
\hline $\mathrm{E}$ & Asplenium contiguum & unknown & \\
\hline $\mathrm{E}$ & Asplenium haleakalense & unknown & \\
\hline E & Asplenium hobdyi & Paleotropics & Schneider et al., 2005 \\
\hline E & Asplenium kaulfussii & unknown & \\
\hline E & Asplenium leucostegioides & unknown & \\
\hline $\mathrm{E}$ & Asplenium macraei & unknown & \\
\hline $\mathrm{E}$ & Asplenium peruvianum var. insulare & Neotropics & * \\
\hline E & Asplenium schizophyllum & unknown & \\
\hline E & Asplenium sphenotomum & unknown & \\
\hline $\begin{array}{l}\mathrm{E} \\
\mathrm{E}\end{array}$ & $\begin{array}{l}\text { Asplenium trichomanes var. densum } \\
\text { Asnlenium }\end{array}$ & & * \\
\hline $\begin{array}{l}\mathrm{E} \\
\mathrm{E}\end{array}$ & $\begin{array}{l}\text { Asplenium unisorum } \\
\text { Athyrium microphyllum }\end{array}$ & $\begin{array}{l}\text { unknown } \\
\text { unknown }\end{array}$ & \\
\hline $\mathrm{E}$ & $\begin{array}{l}\text { Athyrium microphyllum } \\
\text { Callistopteris baldwinii }\end{array}$ & Asia/Indopacific & * \\
\hline $\mathrm{E}$ & Cibotium - 4 species & Neotropics & Geiger et al., 2007 \\
\hline E & Coniogramme pilosa & Asia/Indopacific & * \\
\hline E & Crepidomanes draytonianum & unknown & \\
\hline E & Ctenitis latifrons & unknown & \\
\hline E & Ctenitis squamigera & unknown & \\
\hline E & Cyclosorus boydiae & unknown & \\
\hline E & $\begin{array}{l}\text { Cyclosorus cyatheoides } \\
\text { Cvclosorus }\end{array}$ & unknown & \\
\hline E & $\begin{array}{l}\text { Cyclosorus hudsonianus } \\
\text { Cyclosorus pendens }\end{array}$ & $\begin{array}{l}\text { unknown } \\
\text { unknown }\end{array}$ & \\
\hline $\begin{array}{l}\mathrm{E} \\
\mathrm{E}\end{array}$ & $\begin{array}{l}\text { Cyclosorus pendens } \\
\text { Cyclosorus sandwicensis }\end{array}$ & $\begin{array}{l}\text { unknown } \\
\text { unknown }\end{array}$ & \\
\hline $\mathrm{E}$ & $\begin{array}{l}\text { Cyclosorus sandwicensis } \\
\text { Cyclosorus wailele }\end{array}$ & $\begin{array}{l}\text { unknown } \\
\text { unknown }\end{array}$ & \\
\hline E & Cystopteris douglasii & unknown & \\
\hline $\mathrm{E}$ & Cystopteris sandwicensis & unknown & \\
\hline $\mathrm{E}$ & Deparia cataracticola & Asia & * \\
\hline $\mathrm{E}$ & Deparia fenzliana & Asia & * \\
\hline $\mathrm{E}$ & Deparia kaalaana & unknown & \\
\hline $\mathrm{E}$ & Deparia marginalis & unknown & \\
\hline $\mathrm{E}$ & Deparia prolifera & unknown & \\
\hline E & Diellia clade of Asplenium (6 spp.) & Paleotropics & Schneider et al., 2005 \\
\hline E & Diplazium arnottii & unknown & \\
\hline E & Diplazium molokaiense* & unknown & \\
\hline E & Diplazium sandwichianum & unknown & \\
\hline E & Diplopterygium pinnatum & Asia/Indopacific & Ranker et al., unpub. data \\
\hline $\mathrm{E}$ & Doodia kunthiana & Indopacific & * \\
\hline E & Doodia lyonii & Indopacific & * \\
\hline $\mathrm{E}$ & Doryopteris angelica & unknown & \\
\hline $\mathrm{E}$ & Doryopteris decipiens & unknown & \\
\hline
\end{tabular}


APPEndix 2. Continued.

\begin{tabular}{|c|c|c|c|}
\hline$\underline{\text { Status }}$ & Taxa & $\begin{array}{c}\text { Distribution of } \\
\text { lineage sister to } \\
\text { Hawaiian Lineage }\end{array}$ & References \\
\hline $\mathrm{E}$ & Doryopteris decora & unknown & \\
\hline $\mathrm{E}$ & Doryopteris subdecipiens & unknown & \\
\hline $\mathrm{E}$ & Doryopteris takeuchii & unknown & \\
\hline $\mathrm{E}$ & $\begin{array}{l}\text { Dryopteris crinalis, D. mauiensis, D. sand- } \\
\text { wicensis, D. tetrapinnata, D. unidentata }\end{array}$ & Asia & Geiger and Ranker, 2005 \\
\hline $\mathrm{E}$ & Dryopteris fusco-atra & Asia & Geiger and Ranker, 2005 \\
\hline $\mathrm{E}$ & Dryopteris glabra $+D$. hawaiiensis & Asia & Geiger and Ranker, 2005 \\
\hline $\mathrm{E}$ & Dryopteris rubiginosa & Asia & Geiger and Ranker, 2005 \\
\hline $\mathrm{E}$ & $\begin{array}{l}\text { Dryopteris subbipinnata (sister } \\
\text { to D. wallichiana) }\end{array}$ & Pantropical & Geiger and Ranker, 2005 \\
\hline $\mathrm{E}$ & Elaphoglossum aemulum & unknown & \\
\hline $\mathrm{E}$ & Elaphoglossum alatum & unknown & \\
\hline $\mathrm{E}$ & Elaphoglossum crassicaule & unknown & \\
\hline $\mathrm{E}$ & Elaphoglossum crassifolium & unknown & \\
\hline $\mathrm{E}$ & Elaphoglossum fauriei & unknown & \\
\hline $\mathrm{E}$ & Elaphoglossum parvisquameum & unknown & -4 \\
\hline $\mathrm{E}$ & Elaphoglossum pellucidum & unknown & \\
\hline $\mathrm{E}$ & Elaphoglossum wawrae & unknown & \\
\hline $\mathrm{E}$ & Hymenophyllum lanceolatum & Indopacific & $\begin{array}{l}\text { Ebihara et al., 2004; Hen- } \\
\text { nequin et al., 2003, 2006; } \\
\text { Pryer et al., } 2001\end{array}$ \\
\hline $\mathrm{E}$ & Hymenophyllum obtusum & unknown & \\
\hline $\mathrm{E}$ & Hymenophyllum recurvum & unknown & \\
\hline $\mathrm{E}$ & Hypolepis hawaiiensis & Austral & Ranker et al., unpub. data \\
\hline $\mathrm{E}$ & Lindsaea repens var. macraeana & Asia/Indopacific & * \\
\hline $\mathrm{E}$ & Marattia douglasii & Neotropics & Murdock, 2008 \\
\hline $\mathrm{E}$ & Marsilea villosa & $\begin{array}{l}\text { North America/ } \\
\text { Neotropics }\end{array}$ & Whitten et al., 2012 \\
\hline $\mathrm{E}$ & Microsorum spectrum & Asia & Kreier et al., 2008 \\
\hline $\mathrm{E}$ & Nephrolepis exaltata subsp. hawaiiensis & Pantropical & * \\
\hline $\mathrm{E}$ & $\begin{array}{l}\text { Oreogrammitis baldwinii, O. forbesiana, } \\
\text { O. hookeri }\end{array}$ & Asia/Indopacific & Ranker et al., 2004 \\
\hline $\mathrm{E}$ & Polypodium pellucidum & Boreal & Haufler and Ranker, 1995 \\
\hline $\mathrm{E}$ & Polystichum bonseyi $+P$. haleakalense & Asia & $\begin{array}{l}\text { Driscoll and Barrington, } \\
2007\end{array}$ \\
\hline $\mathrm{E}$ & Polystichum hillebrandii & Asia & $\begin{array}{l}\text { Driscoll and Barrington, } \\
2007\end{array}$ \\
\hline $\mathrm{E}$ & Pseudophegopteris keraudreniana & Asia & * \\
\hline $\mathrm{E}$ & Pteris hillebrandii & unknown & \\
\hline $\mathrm{E}$ & Pteris irregularis & unknown & \\
\hline $\mathrm{E}$ & Pteris lydgatei & unknown & \\
\hline $\mathrm{E}$ & Sadleria - 6 species & unknown & \\
\hline $\mathrm{E}$ & Sceptridium subbifoliatum* & unknown & \\
\hline $\mathrm{E}$ & Schizaea robusta & unknown & \\
\hline E & Stenogrammitis saffordii & Neotropics & Sundue et al., 2010 \\
\hline $\mathrm{E}$ & Sticherus owhyhensis & unknown & \\
\hline $\mathrm{E}$ & Tectaria gaudichaudii & unknown & \\
\hline $\mathrm{E}$ & Thelypteris globulifera & unknown & \\
\hline E & Vandenboschia cyrtotheca & unknown & \\
\hline
\end{tabular}


APPENDIX 2. Continued.

\begin{tabular}{|c|c|c|c|}
\hline Status & Taxa & $\begin{array}{c}\text { Distribution of } \\
\text { lineage sister to } \\
\text { Hawaiian Lineage }\end{array}$ & References \\
\hline $\mathrm{E}$ & Vandenboschia davallioides & unknown & \\
\hline $\mathrm{E}$ & Vandenboschia tubiflora & unknown & \\
\hline I & Adiantum capillus-veneris & Cosmopolitan & * \\
\hline I & Asplenium adiantum-nigrum & Paleotropics & * \\
\hline I & Asplenium aethiopicum & Pantropical & * \\
\hline I & Asplenium caudatum & Asia/Indopacific & * \\
\hline I & Asplenium excisum & Asia/Indopacific & * \\
\hline I & Asplenium insiticium & Indopacific & * \\
\hline I & Asplenium lobulatum & Asia/Indopacific & * \\
\hline I & Asplenium monanthes & Pantropical & * \\
\hline I & Asplenium nidus & Paleotropics & * \\
\hline I & Asplenium normale & Paleotropics & * \\
\hline I & Asplenium polyodon & Paleotropics & * \\
\hline I & Asplenium unilaterale & Paleotropics & * \\
\hline I & Crepidomanes minutum & Asia & * \\
\hline I & Crepidomanes proliferum & Asia/Indopacific & * \\
\hline I & Cyclosorus interruptus & Pantropical & * \\
\hline I & Cyrtomium caryotideum & Asia & * \\
\hline I & Dicranopteris linearis & Paleotropics & * \\
\hline I & Dryopteris wallichiana & Pantropical & * \\
\hline I & Elaphoglossum paleaceum & Neotropics & * \\
\hline I & Haplopteris elongata & Paleotropics & * \\
\hline I & Lepisorus thunbergianus & Asia/Indopacific & * \\
\hline I & Lindsaea repens & Paleotropics & * \\
\hline I & Microlepia speluncae & Paleotropics & * \\
\hline I & Microlepia strigosa & Paleotropics & * \\
\hline I & Nephrolepis cordifolia & Pantropical & * \\
\hline I & Ophioderma pendulum & Paleotropics & * \\
\hline I & Ophioglossum nudicaule & Pantropical & * \\
\hline I & Ophioglossum petiolatum & Pantropical & * \\
\hline I & Ophioglossum polyphyllum & Paleotropics & * \\
\hline I & Pellaea ternifolia & Neotropics & * \\
\hline I & Psilotum complanatum & Pantropical & * \\
\hline I & Psilotum nudum & Pantropical & * \\
\hline I & Pteridium aquilinum & North America & Der et al., 2009 \\
\hline I & Pteris cretica & Cosmopolitan & $\sqrt{2}+2$ \\
\hline I & Pteris excelsa & Paleotropics & * \\
\hline I & Sphenomeris chinensis & Paleotropics & * \\
\hline I & $\begin{array}{l}\text { Tectaria incisa } \\
\text { Lycophytes }\end{array}$ & Neotropics & * \\
\hline $\mathrm{E}$ & Huperzia erosa & unknown & \\
\hline $\mathrm{E}$ & Huperzia mannii & unknown & \\
\hline $\mathrm{E}$ & Huperzia nutans & unknown & \\
\hline $\mathrm{E}$ & Huperzia stemmermanniae & unknown & \\
\hline $\mathrm{E}$ & Huperzia subintegra & unknown & \\
\hline $\mathrm{E}$ & Isoëtes hawaiiensis & Boreal & Hoot et al., 2006 \\
\hline $\mathrm{E}$ & Selaginella deflexa & unknown & \\
\hline I & Selaginella arbuscula & South Pacific & * \\
\hline I & Huperzia erubescens & Asia & * \\
\hline
\end{tabular}


APPENDIX 2. Continued.

\begin{tabular}{cllc}
\hline Status & \multicolumn{1}{c}{ Taxa } & $\begin{array}{c}\text { Distribution of } \\
\text { lineage sister to } \\
\text { Hawaiian Lineage }\end{array}$ & References \\
\hline I & Huperzia filiformis & Tropical America & $*$ \\
I & Huperzia haleakalae & Boreal & $*$ \\
I & Huperzia phyllantha & Asia/Indopacific & $*$ \\
I & Huperzia serrata & Asia & $*$ \\
I & Lycopodiella cernua & Pantropical & $*$ \\
I & Lycopodium venustulum & South Pacific & $*$ \\
\hline
\end{tabular}




\section{$2 \mathrm{BHL}$ Biodiversity Heritage Library}

Vernon, Amanda L and Ranker, Tom A . 2013. "Current Status of the Ferns and Lycophytes of the Hawaiian Islands." American fern journal 103, 59-111. https://doi.org/10.1640/0002-8444-103.2.59.

View This Item Online: https://www.biodiversitylibrary.org/item/200536

DOI: https://doi.org/10.1640/0002-8444-103.2.59

Permalink: https://www.biodiversitylibrary.org/partpdf/231063

\section{Holding Institution}

Missouri Botanical Garden, Peter H. Raven Library

\section{Sponsored by}

Missouri Botanical Garden

\section{Copyright \& Reuse}

Copyright Status: Permission to digitize granted by rights holder Rights: https://www.biodiversitylibrary.org/permissions

This document was created from content at the Biodiversity Heritage Library, the world's largest open access digital library for biodiversity literature and archives. Visit BHL at https://www.biodiversitylibrary.org. 